\title{
Gold in Ferromanganese Deposits from the NW Pacific
}

\author{
Pavel Mikhailik*, Evgenii Mikhailik and Vladimir Ivanov
}

Citation: Mikhailik, P.; Mikhailik, E.; Ivanov, V. Gold in Ferromanganese Deposits from the NW Pacific. Minerals 2021, 11, 979. https:// doi.org/10.3390/min11090979

Academic Editor: Francisco J. González

Received: 16 July 2021

Accepted: 6 September 2021

Published: 8 September 2021

Publisher's Note: MDPI stays neutral with regard to jurisdictional claims in published maps and institutional affiliations.

Copyright: (c) 2021 by the authors. Licensee MDPI, Basel, Switzerland. This article is an open access article distributed under the terms and conditions of the Creative Commons Attribution (CC BY) license (https:// creativecommons.org/licenses/by/ $4.0 /)$.
Laboratory of Regional Geology and Tectonic, Far East Geological Institute, Far East Branch of Russian Academy of Sciences, 690022 Vladivostok, Russia; mikhailik@list.ru (E.M.); d159327@yandex.ru (V.I.)

* Correspondence: mikhailik@fegi.ru; Tel.: +7-914-705-8683

\begin{abstract}
Ferromanganese crusts from four different areas of the North-West Pacific Ocean-the Detroit (northern part of the Imperial Ridge) guyot, the Zubov (Marshall Islands) guyot, the "Gummi Bear" seamount (an intraplate volcano near the Krusenstern FZ), and Belyaevsky volcano (the Sea of Japan)—were studied. Samples from the Detroit and Zubov guyots and the "Gummi Bear" seamount have similar chemical and mineral compositions of hydrogenetic cobalt-rich ferromanganese crusts. Crust from the Sea of Japan seems to reflect a hydrothermal influence. The gold content in most samples from the Detroit guyot was $68 \mathrm{ppb}$ and from the Zubov guyot varied from 180 to $1390 \mathrm{ppb}$, which is higher than the average for the Pacific crusts (55 ppb). Gold content in two other samples was less than $10 \mathrm{ppb}$. Based on the electron microscopic studies, aggregation of gold particles with a size of $680 \mu \mathrm{m}$ were identified in the Detroit guyot crust. The sizes of the Au particles are up to 10-15 $\mu \mathrm{m}$, which has not been previously noted. Gold particles similar in morphology and size were also found in the Zubov guyot crust, which is located far from the Detroit guyot. The largest particle of gold $(\approx 60 \mu \mathrm{m})$, represented by electrum, was found in the clay substrate from the "Gummi Bear" seamount. The lamellar, rudaceous morphology of the gold particles from the Detroit and Zubov guyots reflects their in situ formation, in contrast to the agglutinated, rounded with traces of dragging gold grain found in the substrate of the sample from the "Gummi Bear" seamount. Three-component $(\mathrm{Ag}-\mathrm{Au}-\mathrm{Cu})$ gold particles were found in the hydrothermal crust from the Belyaevsky underwater volcano. Grains similar in composition were also found in Co-rich crust. The research results show that the gold was probably added to by hydrothermal fluid in the already-formed hydrogenetic ferromanganese crusts during rejuvenated volcanic stages. Biogeochemical processes may have played a major role in the formation of submicron solid-phase gold particles.
\end{abstract}

Keywords: ferromanganese deposits; Co-rich crusts; gold; hydrogenic and hydrothermal processes; rejuvenated stage; biogeochemical processes; biomineralization

\section{Introduction}

The gold content in the earth's crust varies from 1 to $6 \mathrm{ppb}$ [1]. The sources of gold deposits are rocks with gold concentrations exceeding those of the earth's crust contents by 2-3 times or more. In nature, there are several mechanisms for the extraction and transport of gold from the mantle and from rocks of various geneses by hydrothermal fluids, including from lithified marine deposits, starting with the Precambrian [2,3]. At the same time, in many continental regions of the world, there are deposits with hyperenrichment of quartz veins in gold ("bonanza" ores, "bonanza" veins) $[4,5]$

The concentration of gold in river water is $0.0001 \mu \mathrm{g} / \mathrm{L}$, and in the ocean it is $0.00002 \mu \mathrm{g} / \mathrm{L}$ or $0.0000001 \mu \mathrm{mol} / \mathrm{L}$ [6]. This difference likely explains the increased concentration of gold in coastal waters and the upper layers of marginal seas [7]. Gold's residence time in seawater is $0.56 \mathrm{Ma}$ [8], which indicates a low Au concentration in marine sediments. However, some types of deposits are sometimes enriched by $\mathrm{Au}$, for example, black shale strata. Organic matter [9], iron, and manganese oxyhydroxides [10] are good sorbents for metals, including gold. In addition, hydrogenetic ferromanganese crusts have extremely 
low growth rates compared to other marine deposits [11,12] (1-10 $\mathrm{mm}$ per million year), which may be an additional factor of their enrichment by gold.

Gold deposits in oceans are well known [13]. Placers are located within shelf areas and continue on the adjacent land and are often associated with primary deposits [14]. Offshore primary deposits with a high concentration of gold are associated with seafloor massive sulfides (SMS) $[15,16]$. The highest gold concentrations (up to $230 \mathrm{ppm}$ ) have been observed within the Papua New Guinea economic zone near Lihir Island [17]. The maximum Au content in this deposit is comparable to the content in bonanza gold deposits [3].

The first data on gold contents in marine ferromanganese deposits were obtained by R.S. Harris et al. [18] for ferromanganese nodules of the Pacific, Atlantic, and Indian oceans. The results showed that Au content varies from $0.21 \mathrm{ppb}$ to $8.28 \mathrm{ppb}$. Oceanic abyssal nodules have a low concentration of gold (4.5 ppb in the Clarion-Clipperton Zone) [12,19-21] in comparison with ferromanganese crusts from seamounts and guyots [12,22]. Co-rich crusts contain on average $30 \mathrm{ppb}$ of gold, and its concentration increases from the Atlantic to the Indian Ocean, reaching a maximum value in the Pacific Ocean $(6,21$, and $35 \mathrm{ppb}$, respectively) [12]. However, one of the seven analyzed layers of Co-rich crusts from the Sierra Leone seamount has the highest $\mathrm{Au}$ content of $156 \mathrm{ppb}$, and the average value is about $75 \mathrm{ppb}$. The bulk sample of the crusts from the HB-9 guyot of the Markus Wake seamounts (Pacific Ocean) contains $75 \mathrm{ppb}$ of gold [23]. This guyot is located in the Crust Prime Zone (CPZ) area, which is characterized by the maximum average gold content in Co-rich crusts for the World Ocean (55 ppm) [12]. The reasons for the increased gold content in Co-rich crusts have not been established. It has been proposed that $\mathrm{Au}$ in Fe-Mn deposits can be derived from seawater and are mainly of terrestrial origin, with a minor cosmogenic component [24]. B. Bolton with coauthors suggested that high $\mathrm{Au}$ concentration in Fe-Mn crusts can be explained by metal-enriched igneous sources which, on degradation, liberated particles of Au which have, in turn, been entrapped in overlying ferromanganese crusts and associated sediments [25]

The given values of gold content in nodules and crusts determine the small size of their particles, as well as an extremely low probability of detection. In Co-rich crusts and nodules, gold was found only by electron microscopic studies. Native gold was found in the form of single elongated-oval particles up to $0.8 \mu \mathrm{m}$ in length in Co-rich crusts, as well as on the surface of vernadite globules and in goethite aggregates of $0.008-0.01 \mu \mathrm{m}$ in size [22]. Native gold was found in the form of rounded and elongated-oval particles up to $0.5 \mu \mathrm{m}$ in nodules, as well as flocculent formations up to $3 \mu \mathrm{m}$ [26].

Currently, ferromanganese Co-rich crusts and deep-sea nodules are considered as promising raw materials for strategic elements (Co, Mn, Mo, etc.). Deep-ocean mineral deposits will not replace land-based mining but will offer an additional source of raw materials to meet the increasing demands [12]. Detailed studies of the element distribution, including noble metals, will increase the economic value of this type of raw material. We determined anomalous gold concentrations (up to $1390 \mathrm{ppb}$ ) in ferromanganese Co-rich crusts from the NW Pacific. This work is devoted to the study of this phenomenon.

\section{Materials and Methods}

\subsection{Materials}

The material for this work were samples of ferromanganese deposits dredged from the Detroit guyot (D13, cruise 91-AV-19/4 of the R/V "Akademik Alexander Vinogradov", 1991), Zubov guyot (33D17-1, the R/V “Gelendzhik" cruise (object 6-07), 2007-2008), the "Gummi Bear" seamount (DR92-11, 249th cruise of the R/V "Sonne", 2016), as well as the underwater Belyaevsky volcano, Sea of Japan $(2069,36$ th cruise of the R/V "Pervenetz", 1980) (Figure 1, Table 1). 


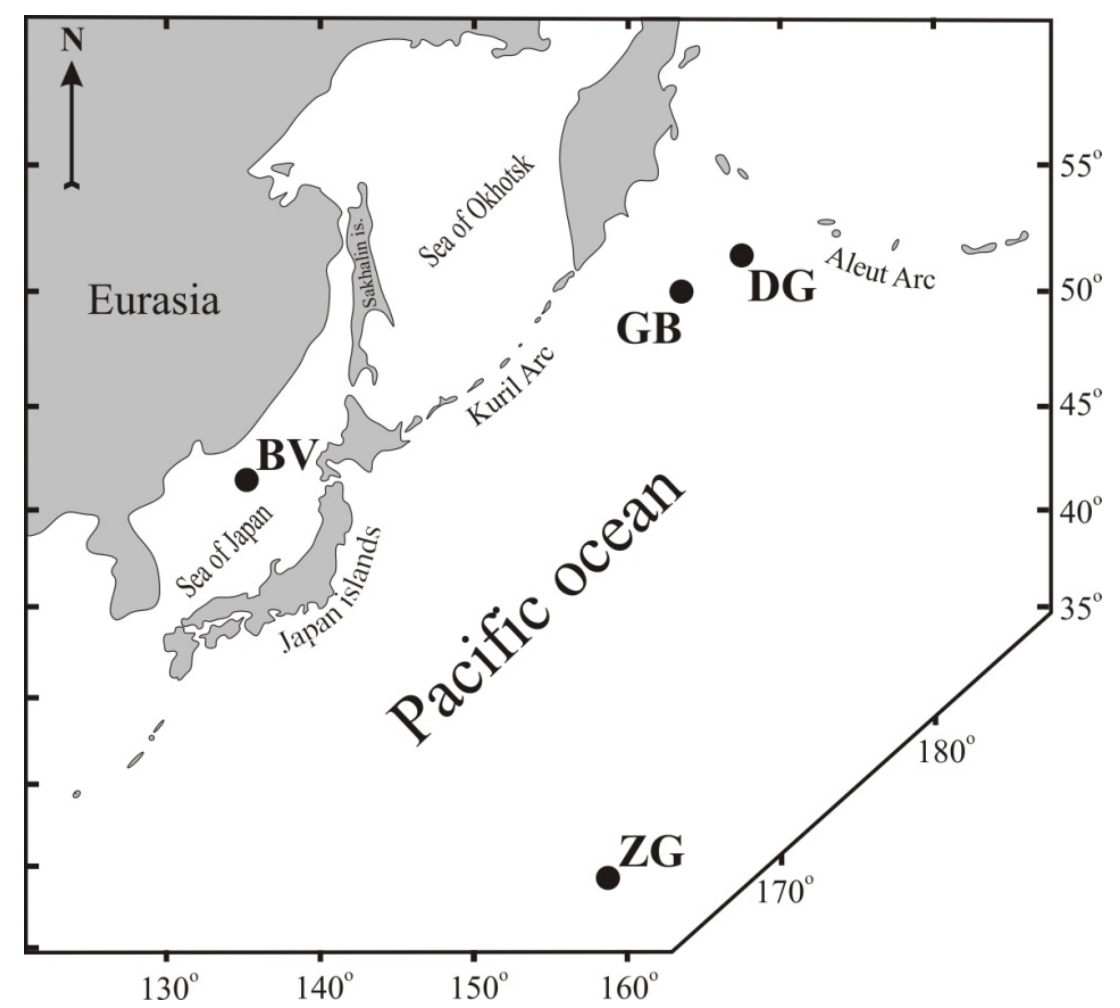

Figure 1. Scheme of the location of ferromanganese deposits. DG: Detroit guyot (D13), ZG: Zubov guyot (33D17-1), GB: Gummi Bear seamount (DR92-11), BV: Belyaevsky underwater volcano (2069).

Table 1. Coordinates of sampling of ferromanganese crusts and geological setting of their location.

\begin{tabular}{ccccc}
\hline $\begin{array}{c}\text { Sample, } \\
\text { Name }\end{array}$ & Latitude, N & Longitude, W & Depth, m & Geologic Setting \\
\hline $\begin{array}{c}\text { D13, } \\
\text { Detroit Guyot }\end{array}$ & $51^{\circ} 29.1^{\prime}$ & $167^{\circ} 38.9^{\prime}$ & 1650 & Guyot \\
\hline $\begin{array}{c}\text { 33D17-1, } \\
\text { Zubov Guyot }\end{array}$ & $15^{\circ} 38.4^{\prime}$ & $160^{\circ} 37.6^{\prime}$ & 2000 & Guyot \\
\hline $\begin{array}{c}\text { DR92-11, } \\
\text { “Gummi Bear” }\end{array}$ & $50^{\circ} 04.8^{\prime}$ & $163^{\circ} 02.8^{\prime}$ & 5043 & Intraplate volcano \\
\hline $\begin{array}{c}2069, \\
\text { Belyaevsky }\end{array}$ & $41^{\circ} 26^{\prime}$ & $134^{\circ} 59.6^{\prime}$ & 2500 & Back-arc volcano \\
\hline
\end{tabular}

The Detroit guyot and the Meiji guyot, sharing a common base, form the Obruchev Rise. These volcanic structures border the Hawaiian-Imperor Chain, which is almost $6000 \mathrm{~km}$ long. Currently, the flat top (plateau) of the guyot is complicated by troughs formed as a result of the activity of underwater currents, as well as ledges and superimposed volcanic cones (Figure 2a), which were formed under water and never rose above the wave-break zone [27-29].

The Zubov guyot is part of the Marshall Islands underwater structures. It is a twopeaked seamount (Figure 2b). The basalt base is overlain by Eocene reef formations overlain by planktonic carbonate oozes [30,31]. Within this guyot, complicating volcanic structures in the form of domes and cones have been established, which are common both within the summit plateau and on the slopes. The density of their distributions within the guyot is 15.9 units/thousand $\mathrm{km}^{2}$ [32].

The "Gummi Bear" seamount (Figure 2c) is located to the west of the Kruzenshtern fracture zone (FZ). This structure is the result of intraplate volcanism. The summit surface 
is overlain by slightly altered aphyric pilow lavas and volcanic rocks with large plagioclase phenocrysts and the presence of fresh glass [33].

The Belyaevsky underwater volcano (Figure 2d) is located in the central basin of the Sea of Japan. It is composed of a Middle Miocene-Pliocene trachybasaltic complex. The volcanic rocks of the Belyaevsky volcano are characterized by fine porosity. The pore volume reaches $40 \%$, which indicates a high fluid saturation of the magma $[34,35]$

a

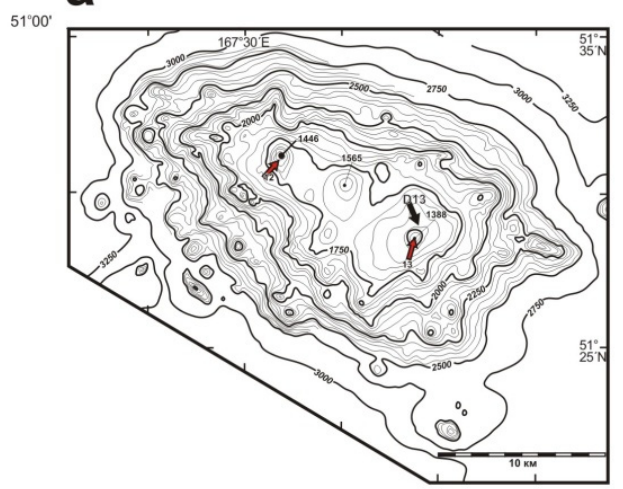

C
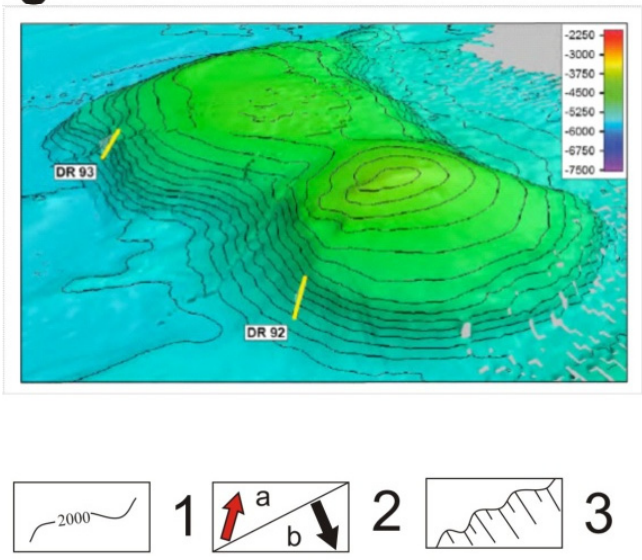

b

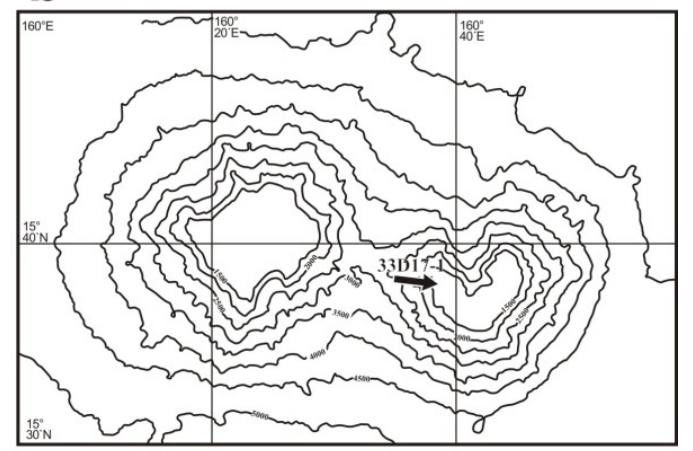

d

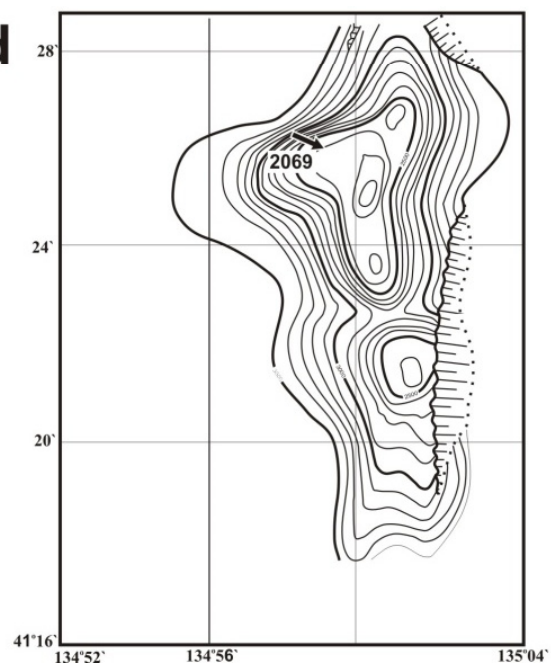

Figure 2. Bathymetry of (a) Detroit guyot's northern superimposed structure [27]; (b) Zubov guyot (our unpublished data); (c) seamount between Krusenstern and N.N. FZ, which has been named "Gummi Bear" seamount by the cruise participants, according to its bathymetric appearance (view from ESE to WSW) [33]; (d) Belyaevsky underwater volcano [36]. 1-isobath; 2-dredging stations, a-after [29], b-our results; 3-cliff.

\subsection{Methods}

The equipment of the Analytical Center of the Far East Geological Institute FEB RAS was used for the complex physicochemical analysis of the crusts.

Investigation of the internal structure of Fe-Mn crusts in cuts of specimens, polished sections, and splinters, as well as targeted sampling of microsamples from them, were carried out using Zeiss Stemi DV4 and Zeiss Axiplan 2 optical microscopes.

The main mineralogical composition was estimated by qualitative powder diffractometry on a MiniFlex II X-ray phase spectrometer (Rigaku, Japan) with CuK-1 radiation and a $\mathrm{Ni}$ selectively absorbing $\beta$-filter. The operating mode of the $X$-ray tube was $30 \mathrm{kV} / 15 \mathrm{~mA}$ at a continuous scanning speed of $1^{\circ} 2 \theta / \mathrm{min}$ in the range of $2.5-60^{\circ}$ at an angle of $2 \theta$. We used the PDF-2 spectrogram database (ICDD 2010) to identify the crystalline phases.

Accessory minerals were studied using extensive analytical scanning electron microscopy. Scanning electron microscopes (SEM) were used (JSM-6490LV, Jeol, Tokyo, Japan) 
with the following energy (EDS) and wave dispersive (WDS) spectrometers: Oxford INCA Energy and INCA Wave, EVO 50XVP (Zeiss, Jena, Germany) with EDS Oxford INCA Energy and field emission LYRA 3 XMH (Tescan, Brno, Czech Republic) with EDS AZtec XMax 80 Standard (Oxford Instruments, Abingdon, UK). The AZtecFeature system (Oxford Instruments) and AZtec software package were used for search automation, classification, and elemental analysis of mineral phases. The preparations for the SEM-EDS-WDS studies were unprocessed flat micro-chips (up to $60 \mathrm{~mm}^{2}$ ) from layers of crusts of different ages, as well as the powders obtained after their sparing (in plastic wrappers) and crushing (fraction, $0.09-0.25 \mathrm{~mm}$ ), which were then attached with carbon tape to aluminum posts. The vacuum deposition of the films on the preparations was carbon.

In the course of the elemental analysis by plasma spectrometry (ICP-AES and ICP-MS), the samples were dried to a constant weight at $105^{\circ} \mathrm{C}$. A weighed portion of the dried test sample $(0.03 \mathrm{~g})$ was placed in a platinum dish; a mixture of concentrated acids (HF, $\mathrm{HNO}_{3}, \mathrm{HClO}_{4}$ ) was added in a ratio of 3:5:1 and evaporated to wet salts; the treatment was repeated with $\mathrm{HNO}_{3}$ and $\mathrm{HClO}_{4}$ acid in a ratio of 1:0.5 and evaporated to wet salts again. Then, the samples were sequentially treated with deionized water and concentrated $\mathrm{HNO}_{3}$, each time evaporating to wet salts. During the sample preparation, a Mn (IV) oxide precipitate was released from the samples. To restore it and convert it into a soluble form, treatment with $1-2 \mathrm{~mL}$ of $30 \% \mathrm{H}_{2} \mathrm{O}_{2}$ and $10 \mathrm{~mL}$ of $26 \% \mathrm{HNO}_{3}$ was performed with heating. Then, the sample solution was transferred into $50 \mathrm{~mL}$ polypropylene volumetric flasks and filled up to the mark with deionized water. Aliquots of $10 \mathrm{~mL}$ for ICP-AES and $2 \mathrm{~mL}$ for ICP-MS were taken from the resulting solutions. Before performing ICP-MS measurements, the solutions were diluted 5 times.

The macrocomponent composition of the crusts ( $\mathrm{Mn}, \mathrm{Fe}, \mathrm{Al}, \mathrm{Ca}, \mathrm{Mg}, \mathrm{Ti}, \mathrm{Na}, \mathrm{K}$, and $\mathrm{P})$ was determined using the multielement method of inductively coupled plasma atomic emission spectrometry (ICP-AES) on an iCAP 7600 Duo spectrometer (Thermo Scientific, Waltham, MA, USA). In this case, the silicon content in the sample was determined by the classical gravimetric method from a weighed portion of $0.1 \mathrm{~g}$ after fusing the powder sample with anhydrous sodium carbonate.

The trace element composition of the samples (Be, Co, Ni, Cu, Zn, Y, Ba, Pb, Th, U, $\mathrm{Mo}, \mathrm{REE}$, etc.) was studied by inductively coupled plasma mass spectrometry (ICP-MS) using an Agilent 7700x spectrometer (Agilent Tech., Tokyo, Japan).

The Au content was determined by the atomic absorption method in the mode of electrothermal atomization on an AA-6800 spectrophotometer (Shimadzu, Kyoto, Japan) by the method of chemical sample preparation with extraction (preliminary separation by coprecipitation with tellurium), which allowed us to avoid the influence of various interferences, including interferences from iron [37]. The applied scheme of acid decomposition of the samples in the determination of gold was as follows:

1. Weighed samples $(2 \mathrm{~g})$ of powder samples were placed in porcelain boats for $3 \mathrm{~h}$ in a muffle furnace at $600{ }^{\circ} \mathrm{C}$ for their mineralization;

2. The mineralization product was transferred into glassy carbon crucibles;

3. A total of $20 \mathrm{~mL}$ of HF conc. was added to the crucibles and left for $10 \mathrm{~h}$;

4. Crucibles with a solution were heated until HF vapor appeared in an electric furnace and evaporated to dryness;

5. A total of $20 \mathrm{~mL}$ of "aqua regia" (3 parts $\mathrm{HCl}$ conc. +1 part $\mathrm{HNO}_{3}$ conc.) was added to the dry residue;

6. This was kept for $20 \mathrm{~min}$, and the solution was evaporated; $5 \mathrm{~mL}$ of "aqua regia" was added again and evaporated to wet salts;

7. Addition of $10 \mathrm{~mL} \mathrm{HCl}$ conc. with evaporation to wet salts;

8. Addition of $5 \mathrm{~mL}$ of $\mathrm{HCl}$ conc. with evaporation to wet salts;

9. Addition of $30 \mathrm{~mL}$ of $1 \mathrm{M} \mathrm{HCl}$ solution. Boiling was performed, and they were filtered into glass beakers and washed with a hot solution of $1 \mathrm{M} \mathrm{HCl}$;

10. Addition of $3 \mathrm{~mL}$ of Te solution (concentration $2 \mathrm{mg} / \mathrm{mL}$ );

11. The solutions were heated on an electric furnace; 
12. Addition of $10 \%$ solution of $\mathrm{SnCl}_{2}$ to a persistently dark color. We then added $10 \mathrm{~mL}$ of excess solution and carried out boiling until the solution became clear;

13. The solutions were filtered; the glasses were washed with hot $2 \mathrm{M} \mathrm{HCl}$; the filtrate was removed;

14. The precipitate was dissolved in $10 \mathrm{~mL}$ of a mixture of $\mathrm{HCl}$ conc. and $\mathrm{H}_{2} \mathrm{O}_{2}$ conc. in a ratio of $1: 1$;

15. The solutions were filtered; the filtrate was washed with warm $1 \mathrm{M} \mathrm{HCl}$ and evaporated to $10 \mathrm{~mL}$;

16. The concentration of $\mathrm{Au}$ was measured in the solutions on a spectrophotometer.

Previously, we obtained some results on the morphology, mineralogy and geochemistry of the ferromanganese crusts from the Detroit guyot [38], and the underwater Belyaevsky volcano [36], which will be used to discuss the origin ferromanganese crusts and gold mineralization into them in the "Results and Discussion" section.

\section{Results and Discussion}

\subsection{Morphology}

The 150-mm-thick ferromanganese crust (Figure 3a) was recovered from the northern slope of the Detroit guyot volcanic cone (Figure 2a). It is characterized by a platy structure. Cracks are visible, both in layers and across it. The upper $18 \mathrm{~mm}$ is distinguished by a brownish color and columnar and platy ultrastructures, which, by morphological features, correspond to layer III of the Co-rich crusts [38,39]. The majority of the sample is represented by a pitch-black anthracite layer (layer I). A thin-layered microstructure prevails in the lower and central parts, and a fine-layered one in the upper part [38]. Thus, the Fe-Mn crust of the Detroit guyot is two-layered and differs strongly from the three-layer crusts of the tropical and subtropical guyots from the Pacific, characterized by the presence of an intermediate section: a porous layer (layer II) [39].
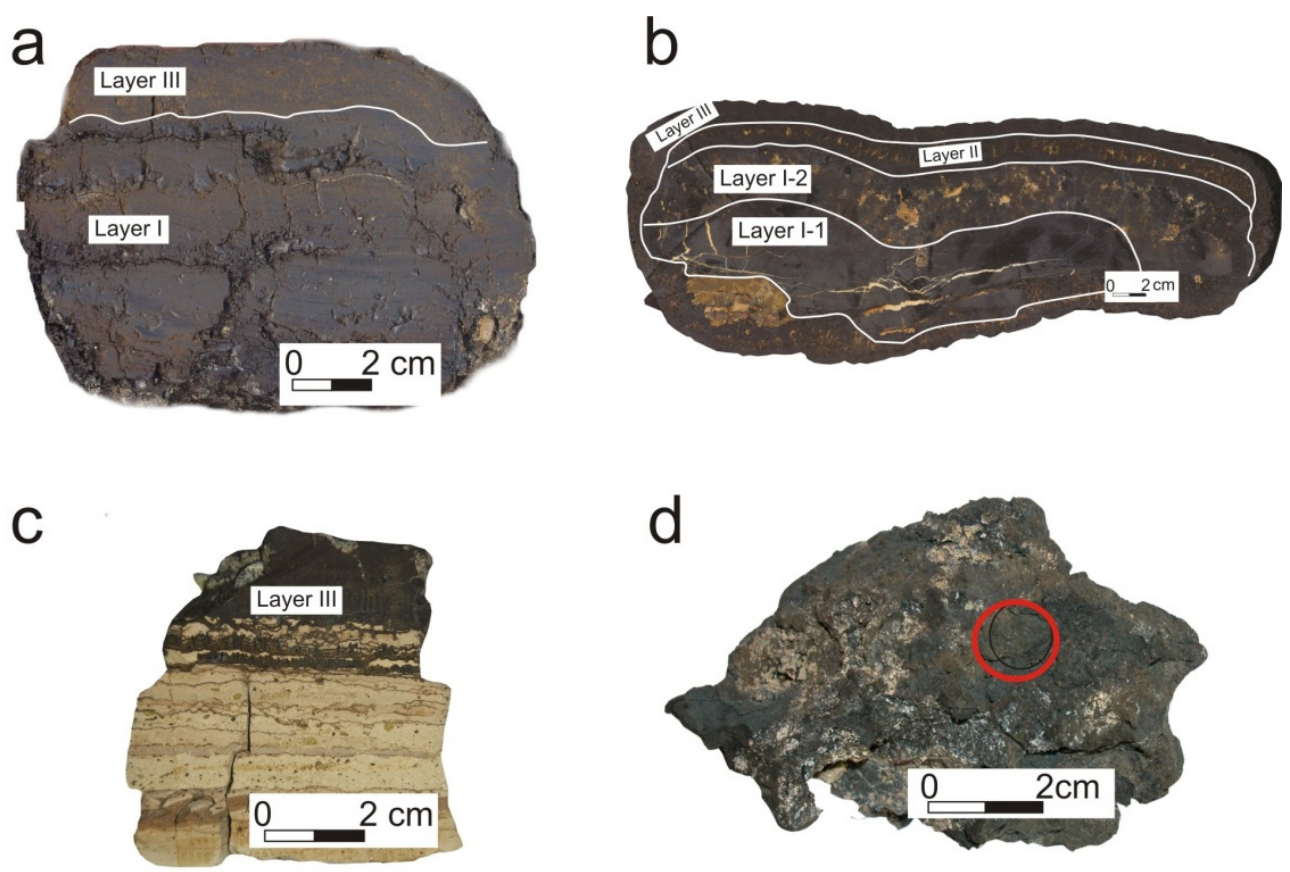

Figure 3. Morphology of ferromanganese crusts: (a): sample D13; (b): sample 33D17-1; (c): sample DR92-11; (d): sample 2069 (red circle-sampling point).

The ferromanganese crust of the Zubov guyot with a thickness of up to $157 \mathrm{~mm}$ (Figure 3b) is represented by typical three-layered Co-rich crusts [39]. The substrate is represented by tuff breccia. The substance in layer I-1 has a blue-black color with a diamond luster. The layer structure is laminated to ultralaminated. It is marked by the presence 
of an interlayer and crosscutting dirty white or yellowish phosphate veins, $0.01-0.3 \mathrm{~mm}$ thick (up to $2 \mathrm{~mm}$ in some places), composed of a phosphatized foraminiferal-nannofossil mass. Next in the cross section is layer I-2. It is similar to layer I-1. The difference is the absence phosphate veins (Figure 3b). The mottled structure is due to the combination of black columns and large globules of iron and manganese hydroxides and a solid, dense phosphate material of light gray or light beige color, filling the interstices between the ore materials. Contact with the underlying layer I-1 is also gradual. Further along the cross section, layer II occurs, which has a radial columnar structure. The columns of manganese and iron hydroxides are black in color; the interstices between them are filled with nonmetallic material of a yellow-brown color. The columns are oriented perpendicular to the growth surface, nearly parallel to each other. The sizes of the interstices can vary, as well as the degree of their filling with a nonmetallic component, which is represented by clay material. The structure of the layer is columnar; the contact with the underlying layer is sharp. Layer III completes the cross section. It is the most variable in thickness. The texture is massive. The color is black with a brownish tint. The color is due to a finely dispersed ocher-colored material scattered among the black iron and manganese hydroxides. This layer completely envelops the sample. This most likely indicates events that led to the separation of the ore substance from the substrate, its destruction, and movement, followed by the resumption of its formation. The contact with layer II is gradual.

The ferromanganese crust from the "Gummi Bear" seamount has a single-layer structure, $31 \mathrm{~mm}$ thick (Figure 3c). The substrate is light gray fractured porous banded silt mudstone. The contact with the substrate is sharp. The texture of the ore substance is thin-layered and its color is dark brown. The lower part of the ore mass contains clay layers. This indicates a frequent change in the hydrodynamic regime in the region of the formation of this sample. In its morphology, the ore of the crust corresponds to the brown coal layer of the ferromanganese crust of the Detroit guyot, which indicates similar conditions for the formation of these layers.

The ferromanganese crust of the Belyaevsky underwater volcano is without substrate (Figure 3d). The photograph shows the surface of sample 2069. Its thickness is $46 \mathrm{~mm}$. The ore substance is pitch-black in color, with a strong metallic luster at the fracture. On the smoothed lower surface in depressions and pits alternating with protrusions that are small in height, there are yellowish-gray discharges of loose clay. The surface is heterogeneous and looks smooth, rough, small-tuberous, tuberous, and groin-like (botryoidal) [37].

\subsection{Mineralogy}

The mineral composition (Table 2) of all the ore layers in the samples of the open part of the Pacific is represented by vernadite $\left(\delta-\mathrm{MnO}_{2}\right)$ [38-40], except for the base of the anthracite layer of sample D13, where bernessite, $10 \AA$ A-manganite, and CFA are noted [38]. The latest data also comprise veins and interstices of layers I-1 and I-2 of sample 33D17-1.

Among the nonmetallic minerals, quartz, plagioclase, and clay minerals were identified, with their maximum amount in the upper brownish-brown layers. This mineral composition is typical of the hydrogenic crusts of the Pacific seamounts and guyots [12].

According to J. R. Hein and S. Wisman [41], marine hydrothermal ferromanganese deposits have a relatively simple mineral composition. However, the ferromanganese crust of the Belyaevsky underwater volcano is distinguished by a complex mineral composition [42]. In addition to the previously established vernadite, burnessite and todorokite, and manganite and pyrolusite indicating a hydrothermal genesis [37], there are manganosite, quenselite, tungomelan, manganotantalite, and rhodochrosite [42]. 
Table 2. Mineral composition of ferromanganese crusts.

\begin{tabular}{|c|c|c|}
\hline Sample & Interval/Section & Mineral Composition \\
\hline \multirow{2}{*}{ D13 } & $0-103, \mathrm{~mm}$ & vernadite $(\delta-\mathrm{MnO} 2)$, quartz, plagioclase, clay minerals \\
\hline & 103-120, mm & vernadite ( $\delta$-MnO2), bernessite, $10 \AA$ A-manganite, CFA \\
\hline \multirow{2}{*}{ 33D17 } & layer II; III & vernadite $(\delta-\mathrm{MnO} 2)$, quartz, plagioclase, clay minerals \\
\hline & laeyr I-1; I-2 & vernadite $(\delta-\mathrm{MnO} 2), \mathrm{CFA}$ \\
\hline DR92-11 & layer III & vernadite $(\delta-\mathrm{MnO} 2)$, quartz, plagioclase \\
\hline 2069 & bulk & $\begin{array}{c}\operatorname{vernadite}(\delta-\mathrm{MnO} 2) \text {, burnessite, todorokite, manganite, pyrolusite, manganosite, } \\
\text { quenselite, tungomelan, manganotantalite, rhodochrosite. }\end{array}$ \\
\hline
\end{tabular}

\subsection{Geochemistry}

Table 3 shows the chemical composition of the studied samples. The $\mathrm{Mn} / \mathrm{Fe}$ ratios for samples from the open part of the ocean, morphologically assigned to layer III, for the Zubov guyot and the Gummi Bear seamount are approximately equal and amount to 1.45 and 1.43, respectively. The concentration of Fe in the ferromanganese crust of the Detroit guyot is greater (Table 3), so the magnitude of the $\mathrm{Mn} / \mathrm{Fe}$ ratios is much lower and varies from 0.32 to 0.86 . Moreover, the $0-5 \mathrm{~mm}$ interval in Detroit guyot's Fe-Mn crust has the highest concentration of iron in relation to the other layers. Despite its sharp increase (about $10 \%$, Table 3), the amount of silicon and aluminum is lower (Table 2) than in the underlying layer (interval of $5-18 \mathrm{~mm}$ ). This may indicate that iron is part of the vernadite structure and is not contained in the aluminosilicate fraction. The anthracite layer (layer I) of the Detroit guyot crust is characterized by higher concentrations of manganese relative to iron (Table 3). Layers with a concentration $\mathrm{P}>0.7 \%$ are considered to be phosphatized crusts [43]. In layers with a high phosphorus content, the amount of calcium, which is part of the CFA, increases sharply.

Table 3. Chemical composition and growth rates of ferromanganese crusts.

\begin{tabular}{|c|c|c|c|c|c|c|c|}
\hline \multirow{4}{*}{ Element } & \multicolumn{7}{|c|}{ Detroit Guyot, D13 } \\
\hline & \multicolumn{2}{|c|}{ Layer III } & \multicolumn{5}{|c|}{ Layer I } \\
\hline & \multicolumn{7}{|c|}{ Interval, $\mathrm{mm}$} \\
\hline & $0-5$ & 5-18 & $18-22$ & $22-38$ & $38-58$ & $58-103$ & $103-120$ \\
\hline $\mathrm{Si}(\%)$ & 3.83 & 7.24 & 4.92 & 4.13 & 4.76 & 4.11 & 9.16 \\
\hline $\mathrm{Ti}$ & 0.95 & 0.7 & 0.93 & 0.77 & 1 & 0.95 & 0.72 \\
\hline $\mathrm{Al}$ & 1.55 & 1.73 & 0.82 & 0.48 & 0.79 & 0.89 & 2.06 \\
\hline $\mathrm{Fe}$ & 31.25 & 21.42 & 23.73 & 20.58 & 22.75 & 16.59 & 13.06 \\
\hline $\mathrm{Mn}$ & 9.99 & 18.45 & 21.82 & 24.03 & 22.02 & 27.7 & 18.22 \\
\hline $\mathrm{Mg}$ & 0.91 & 1.01 & 0.98 & 1.05 & 1 & 1.03 & 1.79 \\
\hline $\mathrm{Ca}$ & 1.45 & 2.19 & 2.33 & 2.37 & 2.39 & 2.82 & 6.46 \\
\hline $\mathrm{Na}$ & 1.66 & 2.09 & 2 & 2.08 & 1.99 & 2 & 1.99 \\
\hline $\mathrm{K}$ & 0.55 & 0.7 & 0.55 & 0.48 & 0.53 & 0.72 & 1.27 \\
\hline $\mathrm{P}$ & 0.51 & 0.43 & 0.44 & 0.46 & 0.44 & 0.41 & 2.25 \\
\hline Li (ppm) & 5.73 & 6.64 & 7.76 & 3.53 & 1.9 & 8.8 & 70.8 \\
\hline $\mathrm{Be}$ & 5.5 & 4.9 & 6.2 & 5.28 & 5.7 & 6.2 & 2.7 \\
\hline Sc & 21.1 & 13 & 12 & 10 & 7.9 & 9.2 & 20.3 \\
\hline $\mathrm{V}$ & 748 & 638 & 779 & 758 & 770 & 626 & 339 \\
\hline $\mathrm{Cr}$ & 298 & 83 & 12 & 88 & 5 & 7 & 115 \\
\hline
\end{tabular}


Table 3. Cont.

\begin{tabular}{|c|c|c|c|c|c|c|c|}
\hline \multirow{4}{*}{ Element } & \multicolumn{7}{|c|}{ Detroit Guyot, D13 } \\
\hline & \multicolumn{2}{|c|}{ Layer III } & \multicolumn{5}{|c|}{ Layer I } \\
\hline & \multicolumn{7}{|c|}{ Interval, mm } \\
\hline & $0-5$ & $5-18$ & $18-22$ & $22-38$ & $38-58$ & 58-103 & $103-120$ \\
\hline Co & 2668 & 2887 & 2937 & 3031 & 2845 & 4228 & 1647 \\
\hline $\mathrm{Ni}$ & 803 & 1504 & 2507 & 3260 & 2727 & 4067 & 4293 \\
\hline $\mathrm{Cu}$ & 117 & 362 & 384 & 398 & 415 & 1372 & 730 \\
\hline $\mathrm{Zn}$ & 561 & 482 & 658 & 610 & 630 & 622 & 724 \\
\hline $\mathrm{Ga}$ & n.d. & n.d. & n.d. & n.d. & n.d. & n.d. & n.d. \\
\hline As & n.d. & n.d. & n.d. & n.d. & n.d. & n.d. & n.d. \\
\hline $\mathrm{Rb}$ & 10.2 & 12.8 & 5.98 & 4.54 & 5.3 & 6.6 & 22.1 \\
\hline $\mathrm{Sr}$ & 1216 & 1548 & 1727 & 1757 & 1892 & 1763 & 933 \\
\hline $\mathrm{Y}$ & 168 & 229 & 267 & 223 & 214 & 207 & 551 \\
\hline $\mathrm{Zr}$ & 967 & 613 & 690 & 649 & 519 & 629 & 228 \\
\hline $\mathrm{Nb}$ & 73 & 46 & 59 & 41 & 52 & 83 & 58 \\
\hline Mo & 174 & 625 & 757 & 616 & 823 & 626 & 358 \\
\hline $\mathrm{Cd}$ & 2.8 & 4 & 4.8 & 4.07 & 5.4 & 5.6 & 7.3 \\
\hline Cs & 0.5 & 0.7 & 0.3 & 0.21 & 0.1 & 0.2 & 0.9 \\
\hline $\mathrm{Ba}$ & 1797 & 1978 & 2053 & 1735 & 2373 & 2530 & 2298 \\
\hline $\mathrm{La}$ & 346 & 347 & 416 & 361 & 372 & 322 & 376 \\
\hline $\mathrm{Ce}$ & 1562 & 1116 & 1579 & 1350 & 2472 & 2415 & 709 \\
\hline $\operatorname{Pr}$ & 84 & 79 & 89 & 82 & 93 & 76 & 87 \\
\hline $\mathrm{Nd}$ & 354 & 335 & 382 & 357 & 383 & 311 & 386 \\
\hline $\mathrm{Sm}$ & 76 & 76 & 86 & 77 & 88 & 71 & 87 \\
\hline $\mathrm{Eu}$ & 18 & 19 & 21 & 19 & 21 & 17 & 22 \\
\hline $\mathrm{Gd}$ & 80 & 85 & 102 & 85 & 95 & 83 & 102 \\
\hline $\mathrm{Tb}$ & 10 & 12 & 13 & 13 & 12 & 10 & 14 \\
\hline Dy & 56 & 73 & 80 & 71 & 72 & 61 & 85 \\
\hline Ho & 10 & 14 & 16 & 14 & 14 & 12 & 17 \\
\hline $\mathrm{Er}$ & 28 & 40 & 44 & 40 & 39 & 35 & 49 \\
\hline $\mathrm{Tm}$ & 3.8 & 5.5 & 6.3 & 5.6 & 5.9 & 5.15 & 6.7 \\
\hline $\mathrm{Yb}$ & 25.3 & 36.8 & 42.7 & 38 & 37.9 & 34.5 & 44 \\
\hline $\mathrm{Lu}$ & 3.8 & 5.3 & 6.4 & 5.6 & 5.5 & 5.1 & 6.7 \\
\hline $\mathrm{Hf}$ & 20.3 & 10.9 & 10.9 & 6.7 & 7.2 & 12.1 & 3.9 \\
\hline $\mathrm{Ta}$ & 0.4 & 0.3 & 0.4 & 0.32 & 0.4 & 0.6 & 0.9 \\
\hline W & 27 & 87 & 124 & 127 & 163 & 145 & 63 \\
\hline $\mathrm{Tl}$ & 10 & 27 & 64 & 46 & 51 & 40 & 31 \\
\hline $\mathrm{Pb}$ & 1692 & 1135 & 1548 & 1713 & 1858 & 1439 & 459 \\
\hline Th & 71.9 & 48.1 & 24.9 & 23 & 19.6 & 24.4 & 14.7 \\
\hline $\mathrm{U}$ & 11.3 & 14.8 & 17.7 & 16 & 17.4 & 17.5 & 8.5 \\
\hline $\mathrm{Au}, \mathrm{ppb}$ & $<10$ & $<10$ & $<10$ & $<10$ & 67 & 68 & $<10$ \\
\hline
\end{tabular}


Table 3. Cont.

\begin{tabular}{|c|c|c|c|c|c|c|c|}
\hline \multirow{4}{*}{ Element } & \multicolumn{7}{|c|}{ Detroit Guyot, D13 } \\
\hline & \multicolumn{2}{|c|}{ Layer III } & \multicolumn{5}{|c|}{ Layer I } \\
\hline & \multicolumn{7}{|c|}{ Interval, $\mathrm{mm}$} \\
\hline & $0-5$ & $5-18$ & $18-22$ & $22-38$ & $38-58$ & $58-103$ & $103-120$ \\
\hline $\mathrm{Mn} / \mathrm{Fe}$ & 0.32 & 0.86 & 0.92 & 1.16 & 1.57 & 1.67 & 1.43 \\
\hline$\Sigma \mathrm{P} 3 \ni+\mathrm{Y}$ & 2825 & 2473 & 3108 & 2741 & 3924 & 3664 & 2542 \\
\hline $\mathrm{R}, \mathrm{mm} / \mathrm{Ma}$ & 6.18 & 5.41 & 5.26 & 4.99 & 5.55 & 2.86 & 4.91 \\
\hline \multirow{4}{*}{ Element } & \multicolumn{4}{|c|}{ Zubov Guyot, 33D17-1 } & “Gumm & DR92-11 & $\begin{array}{c}\text { Belyaevsky } \\
\text { Volcano } \\
2069\end{array}$ \\
\hline & Layer III & Layer II & Layer I-2 & Layer I-1 & \multirow{3}{*}{\multicolumn{2}{|c|}{ Layer III }} & \\
\hline & \multicolumn{4}{|c|}{ Interval, mm } & & & \\
\hline & 0-11 & $11-28$ & $28-65$ & 65-106 & & & \\
\hline $\mathrm{Si}(\%)$ & 3.39 & 4.82 & 1.15 & 1.82 & & & 1.76 \\
\hline $\mathrm{Ti}$ & 1.22 & 1.29 & 0.61 & 0.84 & & & 0.03 \\
\hline $\mathrm{Al}$ & 0.79 & 1.25 & 0.65 & 0.36 & & & 0.62 \\
\hline $\mathrm{Fe}$ & 17.87 & 18.52 & 9.5 & 13.45 & & & 2.85 \\
\hline Mn & 25.93 & 22.97 & 15.49 & 22.87 & & & 49.97 \\
\hline $\mathrm{Mg}$ & 1.01 & 1.01 & 0.69 & 0.71 & & & 1.40 \\
\hline $\mathrm{Ca}$ & 2.82 & 2.94 & 21.63 & 11.16 & & & 1.27 \\
\hline $\mathrm{Na}$ & 1.78 & 1.67 & 1.32 & 1.36 & & & 1.88 \\
\hline $\mathrm{K}$ & 0.49 & 0.67 & 0.41 & 0.37 & & & 1.03 \\
\hline $\mathrm{P}$ & 0.26 & 0.29 & 3.19 & 1.58 & & & 0.05 \\
\hline $\mathrm{Li}(\mathrm{ppm})$ & 3.84 & 2.19 & 10.1 & 4.71 & & & 342 \\
\hline $\mathrm{Be}$ & 4.43 & 5.33 & 2.96 & 5.67 & & & 0.33 \\
\hline Sc & 5.99 & 9.44 & 9.72 & 7.12 & & & 1.51 \\
\hline V & 675 & 636 & 372 & 731 & & & 609 \\
\hline $\mathrm{Cr}$ & 4.88 & 9.58 & 5.85 & 1.58 & & & 8.98 \\
\hline $\mathrm{Co}$ & 6802 & 5414 & 1981 & 2832 & & & 361 \\
\hline $\mathrm{Ni}$ & 4632 & 4165 & 3283 & 3125 & & & 870 \\
\hline $\mathrm{Cu}$ & 1377 & 1340 & 1059 & 1212 & & & 120 \\
\hline $\mathrm{Zn}$ & 618 & 639 & 471 & 592 & & & 231 \\
\hline $\mathrm{Ga}$ & 4.89 & 5.61 & 3.92 & 6.01 & & & 19.1 \\
\hline As & 248 & 215 & 117 & 193 & & & 51.3 \\
\hline $\mathrm{Rb}$ & 4.12 & 10.5 & 6.99 & 3.34 & & & 14.4 \\
\hline $\mathrm{Sr}$ & 1688 & 1564 & 1616 & 1903 & & & 1900 \\
\hline $\mathrm{Y}$ & 147 & 165.4 & 314 & 216 & & & 13.7 \\
\hline $\mathrm{Zr}$ & 662 & 745 & 449 & 604 & & & 15.7 \\
\hline $\mathrm{Nb}$ & 62.3 & 73.3 & 26.5 & 36.3 & & & 1.18 \\
\hline Mo & 562 & 451 & 259 & 686 & & & 251 \\
\hline $\mathrm{Cd}$ & 4.58 & 3.86 & 2.62 & 3.63 & & & 3.26 \\
\hline Cs & 0.03 & 0.58 & 0.63 & 0.03 & & & 0.59 \\
\hline
\end{tabular}


Table 3. Cont.

\begin{tabular}{|c|c|c|c|c|c|c|}
\hline \multirow{4}{*}{ Element } & \multicolumn{4}{|c|}{ Zubov Guyot, 33D17-1 } & \multirow{4}{*}{$\begin{array}{c}\text { “Gummi Bear” DR92-11 } \\
\text { Layer III }\end{array}$} & \multirow{5}{*}{$\begin{array}{c}\text { Belyaevsky } \\
\text { Volcano } \\
2069\end{array}$} \\
\hline & Layer III & Layer II & Layer I-2 & Layer I-1 & & \\
\hline & \multicolumn{4}{|c|}{ Interval, mm } & & \\
\hline & $0-11$ & $11-28$ & $28-65$ & 65-106 & & \\
\hline $\mathrm{Ba}$ & 1647 & 1743 & 1315 & 2470 & 2184 & \\
\hline $\mathrm{La}$ & 271 & 274 & 225 & 344 & 289 & 11.1 \\
\hline $\mathrm{Ce}$ & 988 & 975 & 878 & 1802 & 3444 & 27.1 \\
\hline $\operatorname{Pr}$ & 50.3 & 54.7 & 34.2 & 47.4 & 83 & 2.39 \\
\hline $\mathrm{Nd}$ & 205 & 219 & 145 & 188 & 308 & 10.1 \\
\hline Sm & 42.8 & 47.1 & 28.2 & 33.2 & 76.8 & 2.1 \\
\hline $\mathrm{Eu}$ & 10 & 10.7 & 6.82 & 7.64 & 18.3 & 0.55 \\
\hline $\mathrm{Gd}$ & 45.6 & 47.9 & 36.6 & 40.3 & 72.2 & 2.41 \\
\hline $\mathrm{Tb}$ & 7.64 & 8.08 & 5.7 & 6.77 & 10.6 & 0.39 \\
\hline Dy & 42.8 & 43.3 & 34.6 & 40.9 & 53.6 & 2.41 \\
\hline Ho & 9.01 & 9.00 & 8.4 & 9.42 & 9.67 & 0.49 \\
\hline Er & 26 & 25.7 & 25.2 & 28.3 & 26.6 & 1.44 \\
\hline $\mathrm{Tm}$ & 3.81 & 3.79 & 3.64 & 4.23 & 3.86 & 0.20 \\
\hline $\mathrm{Yb}$ & 23.8 & 22.9 & 22.6 & 26.2 & 24.7 & 1.39 \\
\hline $\mathrm{Lu}$ & 3.67 & 3.47 & 3.79 & 4.10 & 3.58 & 0.2 \\
\hline $\mathrm{Hf}$ & 8.84 & 12.6 & 7.51 & 6.91 & 13.4 & 0.28 \\
\hline $\mathrm{Ta}$ & 0.82 & 0.94 & 0.63 & 0.76 & 0.62 & 0.07 \\
\hline W & 88.1 & 71.7 & 43.6 & 55.9 & 66.8 & 95.1 \\
\hline $\mathrm{Tl}$ & 155 & 163 & 109 & 125 & 117 & 4.18 \\
\hline $\mathrm{Pb}$ & 1673 & 1349 & 756 & 1899 & 805 & 13.5 \\
\hline Th & 10.1 & 11.8 & 2.91 & 9.91 & 59.4 & 0.79 \\
\hline $\mathrm{U}$ & 14.8 & 11.8 & 8.82 & 11.9 & 11.5 & 11.2 \\
\hline $\mathrm{Au}, \mathrm{ppb}$ & $<10$ & $<10$ & 180 & 1390 & $<10$ & $<10$ \\
\hline $\mathrm{Mn} / \mathrm{Fe}$ & 1.45 & 1.24 & 1.63 & 1.7 & 1.43 & 17.5 \\
\hline$\Sigma \mathrm{P} 3 \ni+\mathrm{Y}$ & 1878 & 1912 & 1774 & 2800 & 4574 & 76 \\
\hline $\mathrm{R}, \mathrm{mm} / \mathrm{Ma}$ & 4.25 & 6.83 & 1.89 & 1.29 & 12.3 & 174 \\
\hline
\end{tabular}

Note: DL—detection limit; n.d.—not detected.

In Detroit guyot's Fe-Mn crust, according to the sum of these features, three interlayers are distinguished: the upper (intervals $18-22 ; 22-38 ; 38-58 \mathrm{~mm}$ ), the middle (58-103 $\mathrm{mm}$ ), and the lower phosphatized (103-120 mm, P-2.25\%).

The upper interlayer is characterized by the average values of the concentrations of chemical elements and the $\mathrm{Mn} / \mathrm{Fe}$ ratio in comparison with the upper and lower layers (Table 3). The middle interlayer contains the maximum concentrations of ore $(\mathrm{Mn}, \mathrm{Co}, \mathrm{Ni}$, $\mathrm{Cu}$ ) elements, while those fixing the influx of allotigenic admixtures contain the minimum, which is reflected in the value of the coefficients. For these interlayers, the maximum concentration of rare earth elements and yttrium was established (REY, $Y$ is located between Dy and Ho, according to the value of their ionic radius and electronegativity [44]), which together indicate a hydrogenetic origin. The lower interlayer has a high content of phosphorus and calcium, and, in addition, in terms of the concentration of most trace 
elements and REY, it is close to the phosphatized layers of the Fe-Mn crusts from the equatorial Pacific guyots [43] as well as the Zubov guyot (Table 3).

The chemical composition of the ferromanganese crust of the Zubov guyot generally corresponds to the $\mathrm{CPZ}$ area Co-rich crust, with some differences. The two upper and two lower layers are similar in composition to each other (Table 3), and the indicated pairs of layers differ significantly. The lower pair is characterized by low concentrations of ore-forming metals, low iron content, and high concentrations of phosphates. Layer I-1 has higher contents of manganese and cobalt, and layer I-2 has higher contents of copper and phosphorus (Table 3). The manganese content is highest in the I-1 layer; the Mn/Fe ratio reaches 1.7. The upper pair of layers, on the contrary, exhibits the highest concentrations of trace elements and the lowest for phosphates. For layer II, this pair is characterized by increased concentrations of iron and titanium. The contents of Layer III have high values of manganese, cobalt, and nickel. The amount of copper in these layers is approximately the same. Layer I-1 contains the maximum concentrations of heavy rare earths (Er, $\mathrm{Yb})$, as well as $\mathrm{La}$ and $\mathrm{Ce}$, which is especially important. The Ce concentration in layer I-1 is almost two times higher than the values in the other layers, while the coefficients of variation of the values across the layers do not exceed $25 \%$. The La content in the lower layer is $\approx 30 \%$ more than the content in other points of the section, with variability even lower than that of Ce. The maximum concentrations of $\mathrm{Y}$ are found in the lower phosphatized layers since it is closely associated with phosphates. Europium, $\mathrm{Ho}$, Tm, and Lu, usually attributed to the yttrium subgroup, exhibit relative stability in their distribution along the section.

The ferromanganese crust of the "Gummi Bear" seamount was formed at high latitudes. However, the concentrations of macro elements are close to those of the nonphosphotized layers of the sample from the Zubov guyot (Table 3), and the amount of cobalt and nickel is lower. The copper content is almost the same with Zubov guyot sample. A distinctive feature of the chemical composition of sample DR92-11 is the extreme accumulation of cerium relative to other REY. Its concentration is $3444 \mathrm{ppm}$, and lanthanum is $289 \mathrm{ppm}$. The amount of light REY is higher than in the sample from the Zubov guyot and is comparable to the crust of the Detroit guyot, while the heavy ones are lower in comparison with these two samples.

The chemical composition of the crust from the Belyaevsky underwater volcano is sharply different. Here, a high concentration of manganese is observed $(49.97 \%)$ with a low iron concentration $(2.85 \%)$. The amount of all trace elements is low, with the exception of lithium and barium. The REY amount is only 76 ppm (Table 3).

Thus, ferromanganese crusts from the Detroit and Zubov guyots can be considered as the hydrogenetic Co-rich crust type of marine manganese deposits due to the fact that the concentration of cobalt in all their layers exceeds $0.2 \%$ [45]. Due to the fact that the crust from the "Gummi Bear" seamount has cobalt concentrations $<0.2 \%$, this cannot be attributed to the Co-rich crust. On the other hand, the highest concentrations of cerium (3444 ppm) were revealed in it, and the sum of REY is 4574 ppm, which is typical for Corich crust. Such extreme concentrations of cerium were found in hydrogenetic cobalt-rich ferromanganese formations of the Shatskii seamount [46].

The shale-normalized (PAAS according to [47]) REY of ferromanganese crusts from Detroit and Zubov guyots, as well as the "Gummi Bear" seamount (Figure 4), corresponds to their distribution in the Co-rich crusts [48-50] with a characteristic positive cerium anomaly, with the exception of the bottom layer of sample D13 in which this indicator is 0.9 (Table 3, Figure 4a). In the classification diagram of $\mathrm{Ce}_{\mathrm{SN}} / \mathrm{Ce}_{\mathrm{SN}}{ }^{*}$ vs. $\mathrm{Y}_{\mathrm{SN}} / \mathrm{Ho}_{\mathrm{SN}}$, this sample falls into the area of hydrothermal formations, and in the coordinates $\mathrm{Ce}_{\mathrm{SN}} / \mathrm{Ce}_{\mathrm{SN}}{ }^{*}$ vs. $\mathrm{Nd}$ (ppm), it is located separately but tends to hydrogenetic Fe-Mn deposits (Figure 5). Moreover, this sample has a positive yttrium anomaly (Figure 4a), which corresponds to hydrothermal formations and/or phosphatized layers of hydrogenetic ferromanganese crusts [49]. However, the combined presence of negative cerium and positive yttrium anomalies is noted only for hydrothermal ferromanganese formations, which are characterized by a low amount of REY $[49,51]$. A negative cerium anomaly was established for the 
hydrogenetic ferromanganese crusts of the Central Indian Ridge, the formation of which was subject to hydrothermal influence [52]. Additionally, a non-typical distribution of REY is observed in layer I-1 of sample 33D17-1. The phosphotized layers are characterized by a positive yttrium anomaly, and in this sample it has a negative value (Figure $4 \mathrm{~b}$ ), indicating more oxidized conditions for the formation of this layer. A positive cerium anomaly in sample 2069 (Figure 4d) may indicate the presence of a hydrogenetic substance in the bulk composition of the sample. On the other hand, the linear distribution of heavy REY is a consequence of a significant amount of detritus impurities in the sample. The data on the selective leaching of this sample show that the residual fraction has a significant effect on the total REY concentration in the hydrothermal crusts of the Belyaevsky underwater volcano [53].
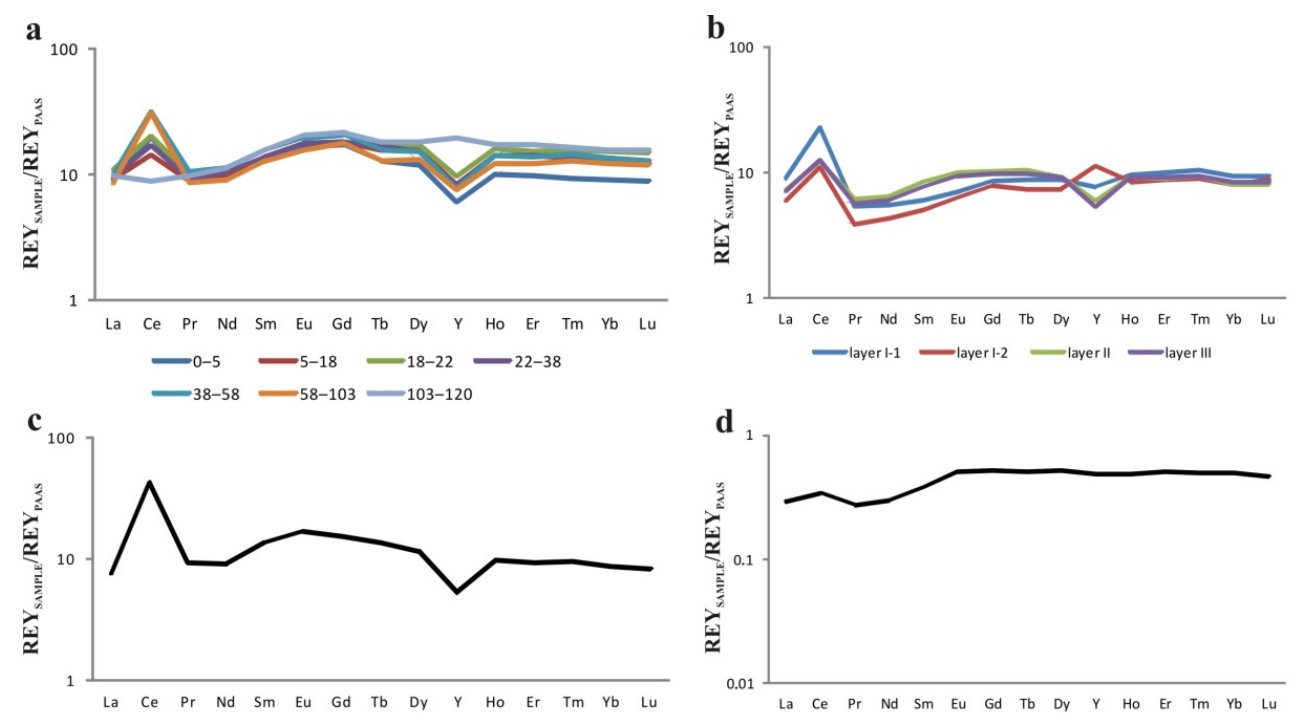

Figure 4. Shale-normalized (PAAS) compositions of REY of ferromanganese crusts. (a) Detroit guyot; (b) Zubov guyot; (c) Gummi Bear seamount; (d) Belyaevsky underwater volcano.

Thus, according to the morphology, mineralogy, and geochemistry, the samples from the open part of the Pacific Ocean correspond to hydrogenetic formations, and from the Belyaevsky underwater volcano to hydrothermal deposits.

\subsection{Growth Rate}

The growth rates calculated using a cobalt chronometer $\mathrm{V}(\mathrm{mm} / \mathrm{Ma})=0.68 / \mathrm{Co}(\%)^{1.67}$ (Co (\%) is the cobalt content in percent) [54] made it possible to calculate the age of the distinguished intervals of sample D13 and to make a correlation with the age of the ferromanganese crust from the same volcanic cone of the Detroit guyot, calculated using data on the isotopic composition of $\mathrm{Nd}$ and $\mathrm{Hf}$ [29] and to confirm the use of a cobalt chronometer for the mathematical calculation of the layers rate. Moreover, the breaks in the crust formation coincide with the breaks in the sedimentation 883 hole (ODP) [27] performed within the Detroit guyot. For the phosphatized layers, the following formula, proposed by [55,56] and modified by [57], was applied:

$$
\begin{gathered}
\text { growth rate }(\mathrm{mm} / \mathrm{Ma})=\frac{1.28}{[\mathrm{Co}]-0.24} \\
\operatorname{Co}(\mathrm{x}) \prime=\operatorname{Co}(\mathrm{x}) \mathrm{m} \frac{\mathrm{Mn} / \mathrm{Co}(\mathrm{x})}{\mathrm{Mn} / \mathrm{Co}(\mathrm{b})} \\
\operatorname{Co}(\mathrm{x})^{\prime \prime}=\frac{\operatorname{Co}(\mathrm{x}) \prime}{1-0.05 \Delta \mathrm{P}}
\end{gathered}
$$


where $\operatorname{Co}(x)^{\prime}$ is the Co concentration of layer $X$ of the phosphatized part corrected for dilution by the CFA phase. $\mathrm{Co}(\mathrm{x}) \mathrm{m}$ and $\mathrm{Mn} / \mathrm{Co}(\mathrm{x})$ are the measured Co content and $\mathrm{Mn} / \mathrm{Co}$ ratio of layer $\mathrm{x}$ of the phosphatized part; $\mathrm{Mn} / \mathrm{Co}(\mathrm{b})$ is the measured $\mathrm{Mn} / \mathrm{Co}$ ratio at the boundary layer between the unphosphatized and phosphatized parts of the crust; and $\Delta \mathrm{P}$ is the difference between the phosphate content of layer $\mathrm{x}$ of the phosphatized part and the average value of the unphosphatized part. $\operatorname{Co}(x)^{\prime}$ is the Co content in layer $x$ of the phosphatized part that is inserted in place of [Co] into Equation (1) to calculate the growth rate of the phosphatized section. $\mathrm{Co}(\mathrm{x})^{\prime \prime}$ is in effect corrected for dilution by the CFA phase and a partial dissolution of the crust by phosphate-rich pore waters.
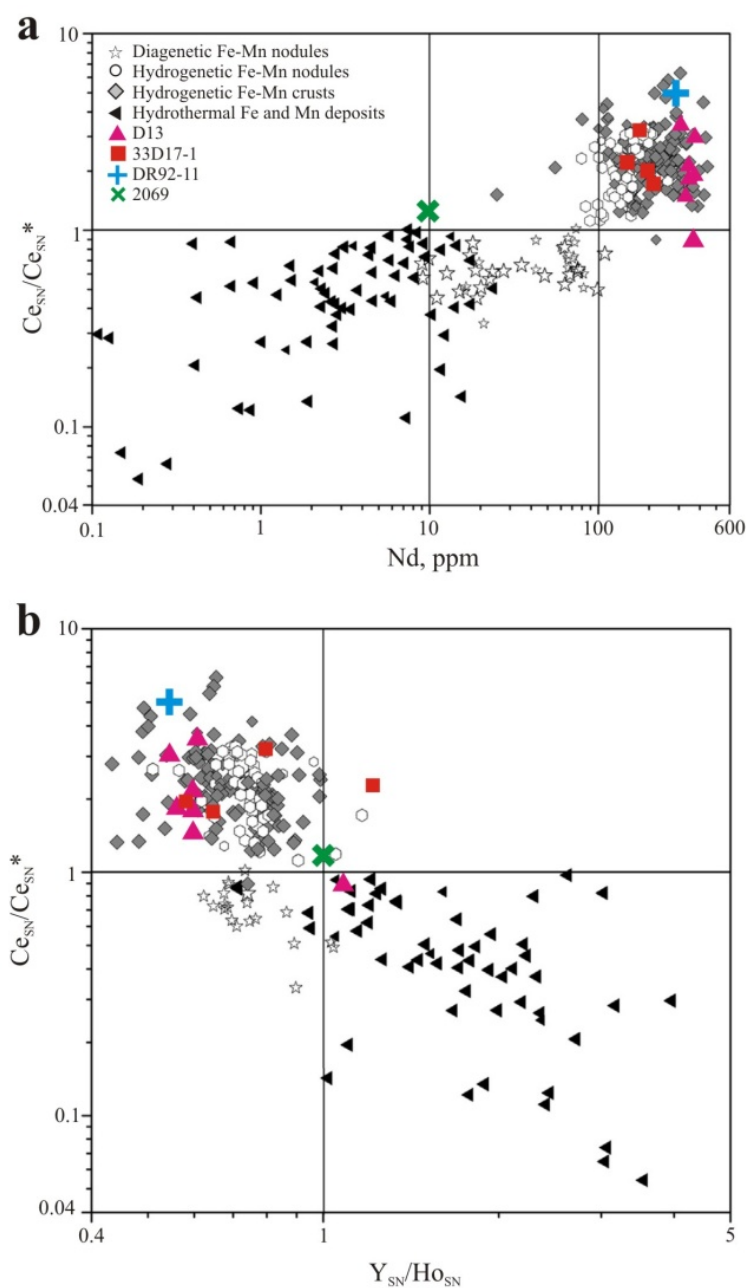

Figure 5. Marine Fe-Mn (oxyhydr) oxide deposits (own data) in graphs of (a) $\mathrm{Ce}_{\mathrm{SN}} / \mathrm{CeS}_{\mathrm{N}}{ }^{*}$ ratio vs. $\mathrm{Nd}$ concentration and $(\mathbf{b}) \mathrm{Ce}_{\mathrm{SN}} / \mathrm{Ce}_{\mathrm{SN}}{ }^{*}$ ratio vs. $\mathrm{Y}_{\mathrm{SN}} / \mathrm{Ho}_{\mathrm{SN}}$ ratio.

The correlation of the D13 crust with 883 hole ODP made it possible to stratigraphically dissect and distinguish three interlayers in the anthracite layer by the time of formation: lower "phosphatized" (Ia: Upper Oligocene, 23-28 Ma), middle (Ib: Lower-Middle Miocene, 23-11.6 Ma) and upper (Ic: Upper Miocene-Lower Upper Pliocene, 11.6-3.6 Ma). The formation of the brown layer (III) occurred during the Late Pliocene-Quaternary (<3.6 Ma) [38]. According to the data of the cobalt chronometer (Table 3), the formation of the ferromanganese crust of the "Gummi Bear" seamount began 2.52 Ma ago, which coincides with the Pliocene-Pleistocene boundary. The time of the formation of the layers of the Zubov guyot's Co-rich crust have established stages: layer I-1: late Paleocene-early Eocene; layer I-2: middle-late Eocene; layer II: Miocene; layer III: Pliocene-Quaternary [39]. The non-growth time of the Co-rich crusts of the central Pacific coincides with the rejuvenated stages of the Pacific plate [39]. The formation of the crust of the Belyaevsky underwater 
volcano began not earlier than the Pliocene, since the minimum K/Ar age of the Belyaevsky seamount is $4.5 \pm 0.5 \mathrm{Ma}[58]$.

\subsection{Gold Concentration}

The conclusions about the hydrogenetic origin of the crusts of the Detroit, Zubov, and "Gummi Bear" seamounts, as well as an analysis of the reference data on the distribution of gold in ferromanganese deposits in the Pacific, suggest that here we can expect a concentration of gold within the average values for the Pacific Ocean (30 ppb, [12]) and the average values in the $\mathrm{CPZ}$ area (55 ppb, [12]).

The distribution of gold in the Co-rich crust of the Detroit guyot shows that two intervals of the anthracite layer (38-58 mm, $67 \mathrm{ppb}$ and 58-103 mm, $68 \mathrm{ppb}$ ) have gold concentrations twice as high as the average for the Pacific Ocean. The largest amount of $\mathrm{Au}$ was determined for the youngest layer of sample 33D17-1 (1390 ppb). Layer II is characterized by lower concentrations (180 ppb). The ore matter of the phosphatized layers, as well as in samples DR92-11 and 2069, has a gold concentration not exceeding $10 \mathrm{ppb}$ (Table 3). Such high concentrations of gold indicate it has an additional source since sorption from seawater and/or replacement does not play a major role in the accumulation of gold by ferromanganese deposits [25].

The high values of gold content in the studied ferromanganese crusts were the basis for the search for its mineral concentrators. The study of Co-rich crust samples by SEM made it possible to detect gold particles in the Detroit and Zubov guyots' Fe-Mn crusts. At the top of the 58-103 mm interval, an accumulation of wedge-shaped gold plates $(680 \mu \mathrm{m})$ was found (Figure 6a), and in the central part of the 38-58 interval, the accumulation of plates reached $30 \mu \mathrm{m}$ (Figure $6 \mathrm{~b}$ ). A gold grain of approximately $15 \mu \mathrm{m}$ was found in the Zubov guyot crust (Figure 6c).
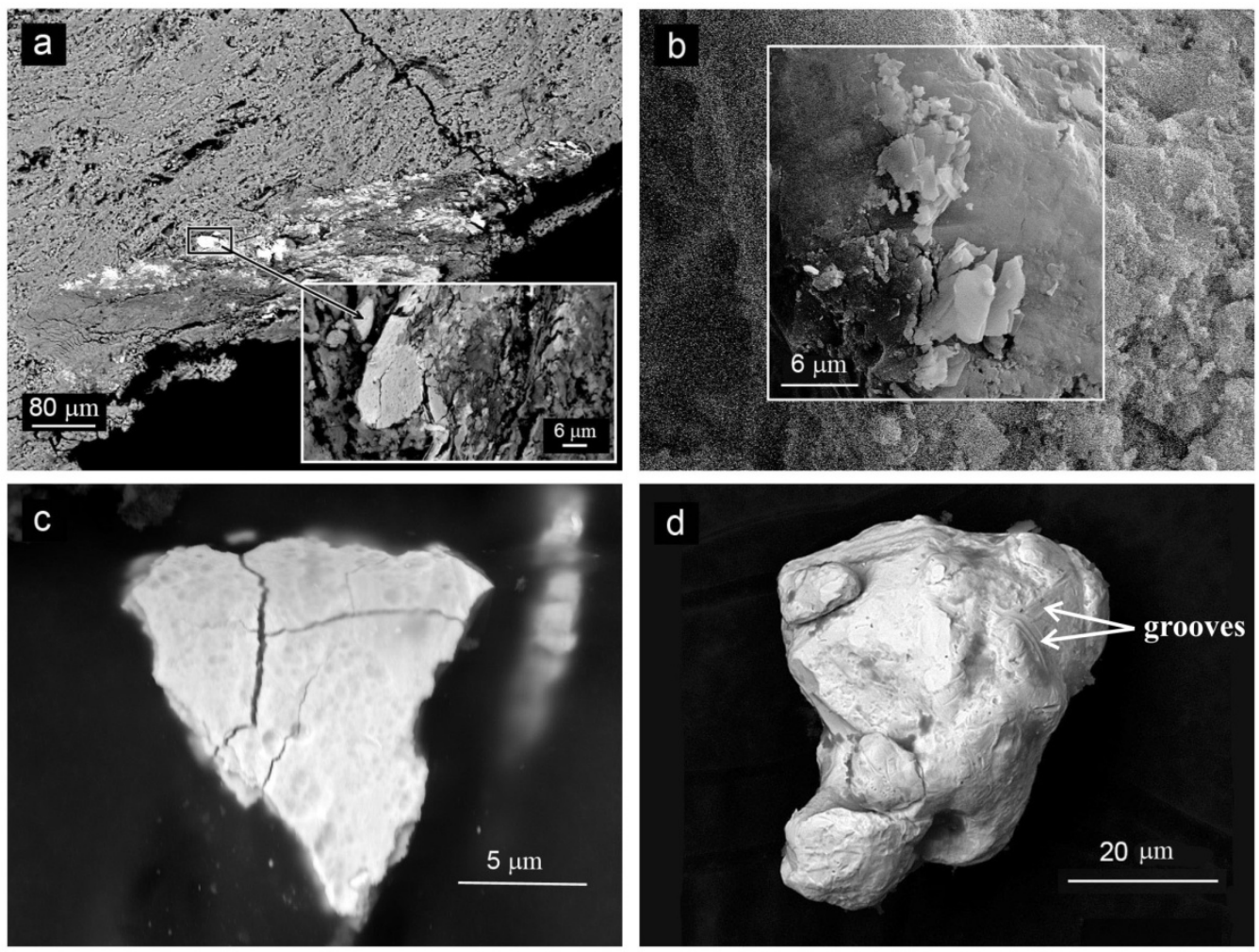

Figure 6. Gold particles in ferromanganese crusts from the Detroit guyot, (a): interval of 58-103 mm (Table 2); (b): interval of 38-58 mm (Table 2); (c): Zubov guyot; (d): “Gummi Bear" seamount.

In the sample from the "Gummi Bear" seamount, no gold grains were found in the ferromanganese substance. However, the study of gold mineralization of hydrogenetic 
ferromanganese crusts in the southwestern Pacific showed that native gold (grain size $\approx$ $10 \mu \mathrm{m}$ ) was found in the clay fraction of the ferromanganese crust or in the altered volcanic substrate [25]. This was the basis for the search for gold minerals in the substrates of the studied samples. In the clay substrate of sample DR92-11, a gold grain of about $60 \mu \mathrm{m}$ was found (Figure 6d).

Fine grains $(1-3 \mu \mathrm{m})$ of this metal are found in the ferromanganese crust of the underwater Belyaevsky volcano (Figure 7). A feature of the gold grains found in ferromanganese crusts of hydrogenetic and hydrothermal genesis is their three-component composition of the Ag-Au-Cu system (Table 4) like in hydrothermal and stratiform deposits of the Sikhote-Alin mountain range [42]. Two-component gold of the Ag-Au system was found for the gold particles of the guyot of the "Gummi Bear" seamount, and the grain on the Zubov guyot was composed of pure gold (Table 4).
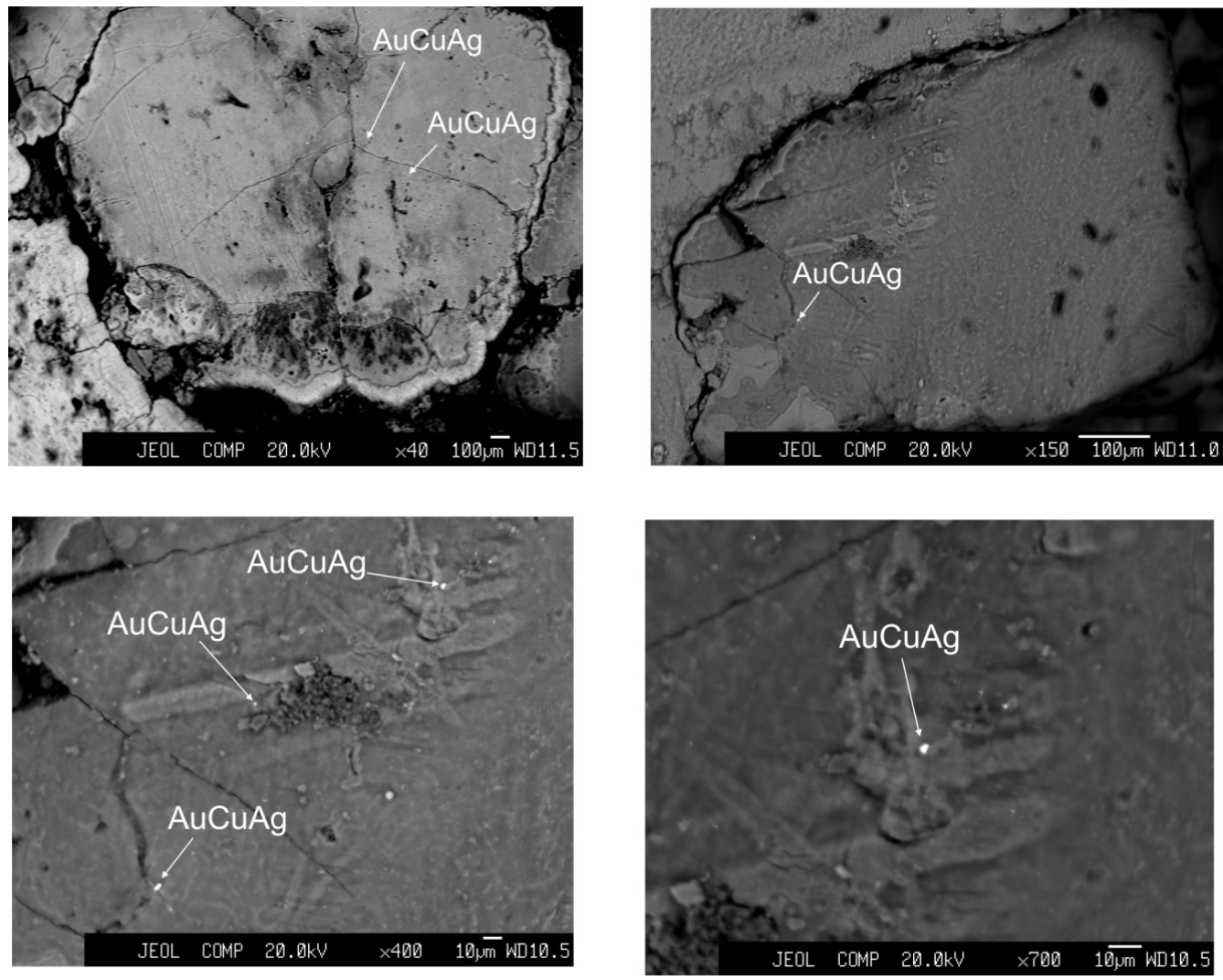

Figure 7. Microparticles of three-component native gold in the ferromanganese crust of the Belyaevsky underwater volcano [42].

Table 4. Results of microanalysis of gold micrograins in ferromanganese crusts, $w \mathrm{t} \%$.

\begin{tabular}{cccccc}
\hline & Sample & Ag & Au & Cu & Sum \\
\hline \multirow{2}{*}{ D13 } & $\begin{array}{c}\text { Detroit guyot } \\
\text { interval 58-103 mm }\end{array}$ & 6.3 & 64.2 & 29.5 & 100 \\
\cline { 2 - 6 } & $\begin{array}{c}\text { Detroit guyot } \\
\text { interval 38-58 mm }\end{array}$ & 23.2 & 10.6 & 66.2 & 100 \\
\hline 33D17-1 & Zubov guyot & - & 100 & - & 100 \\
\hline 92DR-11 & “Gummi Bear" seamount & 37.8 & 62.2 & 700 \\
\hline 2069 & Belyaevsky underwater volcano & 8.1 & 70.4 & 21.2 & 99.7 \\
\hline
\end{tabular}

Note: The results are shown after excluding matrix component impurities. 
There are oval tubercles and depressions on the surface of gold micrograins from the middle and upper layers of the Detroit guyot Co-rich crust, and a small number of pores are also visible. Traces of friction (scratches, grooves) on the plates were not found, which indicates an in situ origin. On the contrary, the grain of sample DR92-11 is a consequence of the agglutination of several grains on the surface of which traces of drawing and movement are noted (Figure 6). The surface morphology of the Detroit guyot gold plates is in many respects similar to the collomorphic cellular structure of the ferromanganese layers both on the bedding (growth) surface and along the planes of cross sections, and is essentially a replica of them. Moreover, it is worth noting the identity of the grain surface morphology for the Detroit and Zubov guyots (Figure 6), which may indicate a common mechanism of their formation.

The morphology and chemical composition of gold plates in the Detroit guyot Corich crust indicate their deposition in thin cracks developed in various directions. The accumulation of these particles was found on the eroded surface of the central part of the crust's cross section, confined to the boundary between the Middle and Late Miocene [38]. In the ferromanganese crust of the Zubov guyot, gold is found at the boundary of layers II and III.

The non-deposition periods (destruction, disintegration) of ferromanganese crusts are associated with rejuvenated stages of the Pacific plate. As a result of these global rearrangements, volcanism resumed on the Jurassic-Cretaceous seamounts and the guyots of the Pacific Ocean, with the formation of superimposed structures having a Cenozoic time of formation both in the northwestern and northeastern segments of the Pacific [32,59].

Hydrothermal fluids may be 1000 times more enriched with gold [7] relative to seawater. This is a consequence of the formation of its high concentrations in deepwater polymetallic sulfides of various geodynamic settings [60-62]. It is deduced that the additional supply of gold in the studied ferromanganese crusts is carried out by hydrothermal fluids produced during the epochs of volcano-tectonic activations.

This scheme is compatible with the results of a detailed analysis of native copper and atacamite plates found in the core of hole 884 ODP both in the basalts and in the overlying sedimentary rocks up to the Middle Miocene [27]. Copper mineralization in the core is confined only to the fault zones. In addition, in association with gold plates in a sample from the upper anthracite interlayer of the Detroit guyot Co-rich crust, we encountered a small plate of native copper (Figure 8). Moreover, cuprous gold is found in the hydrothermal crust of the Belyaevsky underwater volcano, and it is also found in the continental stratiform manganese deposits of the Sikhote-Alin mountain range [42], which were formed in marine environments [63].
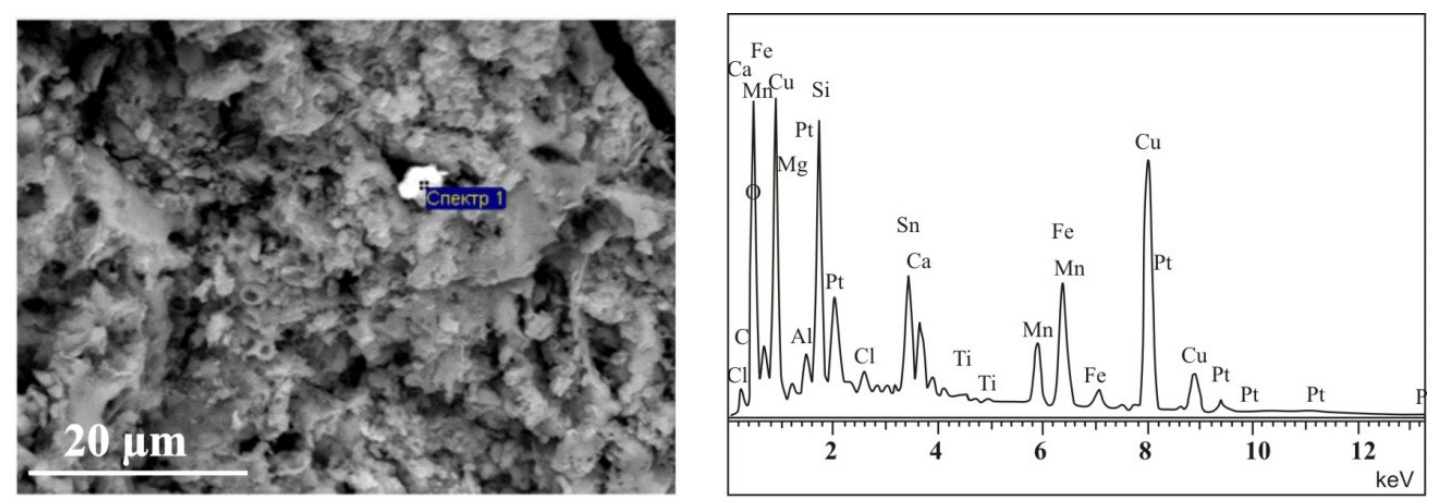

Figure 8. Micrograin copper in the Detroit guyot CMC (platinum plated). Electron microscopic image and EMF spectrum of the composition (platinum deposition).

The low-temperature formation of the researched ores in the cold marine environment is also characterized by the deficiency of reducing agents necessary for the destabilization of the prevailing halogen- and hydroxy-complex gold ions [64]. The deposition of Au in 
geochemical barriers requires determining the cause of occurrence of such reducing conditions in this highly oxidizing environment. This may be aroused by the disproportionate reactions during the transitions of polyvalent $\mathrm{Mn}$ and $\mathrm{Fe}$ into a higher oxidative state.

Taking into account the results obtained due to the numerous model experiments on the active participation of microorganisms (bacteria, microalgae, micromycetes, yeast, etc.) in native metal minerogenesis in various media $[65,66]$, we suppose that the biogeochemical processes may play a key role in the crystallogenesis of the bulk of the accessory minerals of precious metals and the pathfinder elements of the last ones in Co-rich crusts. The growth of productivity and diversity of the benthic microbiota which is ubiquitous in terms of habitat was also favored by the above-mentioned influx of heat and matter into the bottom part of the hydrosphere. Microbial cells have a high potential for extracting ions of noble and other metal from solutions due to the perimembrane sorption and/or intracellular accumulation [67].The self-organization of the segregation occurs during the further subsequent restoration of the adsorbed ions with the last ones reaching its zero state which results in the following: small metal clusters (mono- or multi-element) $\rightarrow$ nano-sized solid particles (colloid-dispersed and submicroscopic) $\rightarrow$ micro-sized massive grains (due to collective crystallization), with the multicomponent ones not being an exception [40].

Thus, the presence of submicron mineral phases of gold in the pores of the samples, which were randomly selected from the collection of the hydrogenic crusts dredged from great depths in different parts of the NW Pacific Ocean, allows revising the existing views on the sporadic frequency of occurrence and the origin of these mineral-accessories of ferromanganese oxyhydroxide ores. For the first time, these findings of natural gold-based alloys point to a wider distribution of autigenic native metal gold mineralization in pelagic Co-rich crust than has been known before.

The biogeochemical reducing processes may have been the major reason for the formation of the gold mineral phases, including the biosorption, bioaccumulation, and biotransformation of ions of Au to the metallic elementary nano- and micro-grains.

\section{Conclusions}

In the Co-rich crusts from the NW Pacific, high concentrations of gold up to $1390 \mathrm{ppb}$ have been established. The rare occurrence of such high concentrations of gold in ferromanganese crusts indicates the heterogeneity of its distribution in ferromanganese deposits samples and may also be due to a lack of specialized studies. Our results indicate the need to increase the mass of an analytical sample up to $2 \mathrm{~g}$, in contrast to the previously proposed methods [68], to reveal the real concentrations of this metal.

Detailed electron microscopic and micro X-ray spectral studies of both polished sections and crushed matter (chips) of ferromanganese crusts of different geneses have shown that gold in them can form a large accumulation of particles. A three-component composition of $\mathrm{Ag}-\mathrm{Au}-\mathrm{Cu}$ grains was revealed both in hydrogenetic crusts and in hydrothermal and stratiform deposits of the Sikhote-Alin mountain range. This indicates an additional hydrothermal source of the substance involved in the gold mineralization of hydrogenetic ferromanganese crusts.

The lamellar and angular morphology of gold micrograins indicates there in situ formation, in contrast to smoothed micrograins with signs of movement established in the substrate of sample DR92-11.

The studies carried out indicate that the formation of gold mineralization under the conditions of hydrogenetic ferromanganese mineralization may occur due to the supply of gold by hydrothermal solutions during rejuvenated stages of the Pacific plate, and its deposition, with a high degree of probability, is a consequence of biomineralization.

Author Contributions: P.M. and E.M. were responsible for most of the writing, although all authors contributed to the final manuscript; the analytical work was completed by V.I.; data analyses and interpretations were predominantly by P.M. and E.M., but all authors contributed. All authors have read and agreed to the published version of the manuscript. 
Funding: This study funded and supported by project 18-17-00015 of the Russian Science Foundation, https:/ / rscf.ru/en/project/18-17-00015/ (accessed on 5 September 2021).

Acknowledgments: Sample from the Gummi Bear mountain was dredged during the expedition of the R/V "Sonne" So 249 under the "Bering" project, supported by the German BMBF. We thank M.E. Melnikov who supplied samples from the Zubov guyot and three unknown referees for their constructive reviews that greatly improved this article.

Conflicts of Interest: The authors declare that the research was conducted in the absence of any commercial or financial relationships that could be construed as a potential conflict of interest. Any use of trade, product, or firm names is for descriptive purposes only and does not imply endorsement by the authors or their affiliated institutions.

\section{References}

1. Jones, R.S. Gold in Meteorites and in the Earth's Crust; U.S. Geological Survey: Reston, VA, USA, 1968.

2. Nekrasov, I.Y. Geochemistry, Mineralogy and Genesis of Gold Deposits; Routledge: London, UK, 1996; p. 344. [CrossRef]

3. Nguimatsia, D.F.W.; Bolarinwa, A.T.; Yongue, R.F.; Ndikumana, J.d.D.; Olajide-Kayoude, J.O.; Olisa, O.G.; Abdu-Salam, M.O.; Kamga, M.A.; Djou, E.S. Diversity of Gold Deposits, Geodynamics and Conditions of Formation: A Perspective View. Open J. Geol. 2017, 7, 1690-1709. [CrossRef]

4. Petrella, L.; Thébaud, N.; Fougerouse, D.; Evans, K.; Quadir, Z.; Laflamme, C. Colloidal gold transport: A key to high-grade gold mineralization? Miner. Depos. 2020, 55, 1247-1254. [CrossRef]

5. McLeish, D.F.; Williams-Jones, A.E.; Vasyukova, O.V.; Clark, J.R.; Board, W.S. Colloidal transport and flocculation are the cause of the hyperenrichment of gold in nature. Proc. Natl. Acad. Sci. USA 2021, 118, e2100689118. [CrossRef] [PubMed]

6. White, W.M. Geochemistry; Wiley-Blackwell: Hoboken, NJ, USA, 2013; ISBN 978-0-470-65667-9.

7. Kenison Falkner, K.; Edmond, J.M. Gold in seawater. Earth Planet. Sci. Lett. 1990, 98, 208-221. [CrossRef]

8. Goldberg, E.D. Chemistry-The oceans as a chemical system. In Composition of Seawater, Comparative and Descriptive Oceanography of the Sea: New York; Hill, M.N., Ed.; Interscience Publishers: Geneva, Switzerland, 1963; Volume 2, pp. 3-25.

9. Gatellier, J.; Jean-RobertDisnar, J. Kinetics and mechanism of the reduction of $\mathrm{Au}(\mathrm{III})$ to $\mathrm{Au}(0)$ by sedimentary organic materials. Organ. Geochem. 1990, 16, 631-640. [CrossRef]

10. Koschinsky, A.; Hein, J.R. Uptake of elements from seawater by ferromanganese crusts: Solid phase associations and seawater speciation. Mar. Geol. 2003, 198, 331-351. [CrossRef]

11. Frank, M.; O'Nions, R.K.; Hein, J.R.; Banakar, V.K. 60 Myr records of major elements and Pb-Nd isotopes from hydrogenous ferromanganese crusts: Reconstruction of seawater paleochemistry-implications for sediment provenance and the source of trace metals in sea water. Geochim. Cosmochim. Acta 1999, 63, 1689-1708. [CrossRef]

12. Hein, J.R.; Mizell, K.; Koschinsky, A.; Conrad, T.A. Deep-ocean mineral deposits as a source of critical metals for high- and green-technology applications: Comparison with land-based resources. Ore Geol. Rev. 2013, 51, 1-14. [CrossRef]

13. Haldar, S.K. (Ed.) Chapter 2-Economic Mineral Deposits and Host Rocks. In Mineral Exploration; Elsevier: Amsterdam, The Netherlands, 2013; pp. 23-39. [CrossRef]

14. Reimnitz, E.; Plafker, G. Marine Gold Placers along the Gulf of Alaska Margin; USGS: Reston, VA, USA, 1976; p. 1415. [CrossRef]

15. Fuchs, S.; Hannington, M.D.; Petersen, S. Divining gold in seafloor polymetallic massive sulfide systems. Min. Depos. 2019, 54, 789-820. [CrossRef]

16. Spiess, F.N.; Macdonald, K.; Atwater, T.; Ballard, R.D.; Carranza, A.; Cordoba, D.; Cox, C.; Garcia, V.M.; Francheteau, J.; Guerrero, J.; et al. East Pacific Rise: Hot springs and geophysical experiments. Science 1980, 28, 1421-1433. [CrossRef]

17. Petersen, S.; Herzig, P.M.; Hannington, M.D.; Jonasson, I.R.; Arribas, A. Submarine Gold Mineralization Near Lihir Island, New Ireland Fore-Arc, Papua New Guinea. Econ. Geol. 2002, 97, 1795-1813. [CrossRef]

18. Harris, R.C.; Crocket, J.H.; Stainton, M. Palladium, iridium and gold in deep sea manganese nodules. Geochim. Cosmochim. Acta 1968, 32, 1049-1056. [CrossRef]

19. Keys, R.R.; Scott, R.B. Precious metals in ocean-ridge basalts: Implications for basalts as a source rock for gold mineralization. Econ. Geol. 1976, 71, 705-720. [CrossRef]

20. Frakes, L.F.; Exon, N.F.; Granath, J.W. Chemistry of manganese nodules from Cape Leeuwin field off Western Australia. BMR J. Aust. Geol. Geophys. 1977, 2, 232-233.

21. Glasby, G.P.; Keays, R.R.; Rankin, P.C. The distribution of rare earth, precious metals and other trace elements in Recent and fossil deep-sea manganese nodules. Geochem. J. 1978, 12, 229-243. [CrossRef]

22. Baturin, G.N.; Konopleva, E.V.; Dubinchuk, V.T.; Melnikov, M.E. Platinum and gold in the ferromanganese crusts of the Pacific Ocean. Oceanology 2005, 45, 269-276.

23. Asavin, A.M.; Anikeeva, L.I.; Kazakova, V.A.; Andreev, S.I.; Sapozhnikov, D.A.; Kogarko, L.N. Trace element and PGE distribution in layered ferromanganese crusts. Geochem. Int. 2008, 46, 1179-1205. [CrossRef]

24. Banakar, V.K.; Hein, J.R.; Rajani, R.P.; Chodankar, A.R. Platinum group elements and gold in ferromanganese crusts from Afanasiy-Nikitin seamount, equatorial Indian Ocean: Sources and fractionation. J. Earth Syst. Sci. 2007, 116, 3-13. [CrossRef] 
25. Bolton, B.; Ostwald, J.; Monzier, M. Precious metals in ferromanganese crusts from the south-west Pacific. Nature 1986, 320, 518-520. [CrossRef]

26. Baturin, G.N.; Dubinchuk, V.T. Microstructures of Oceanic Ferromanganese Nodules; Nauka: Moscow, Russia, 1989 ; p. 288.

27. Rea, D.K.; Basov, L.A.; Scholl, D.W.; Allan, J.F. (Eds.) Proceedings ODP, Science Results; Ocean Drilling Program: College Station, TX, USA, 1995; Volume 145, p. 690. [CrossRef]

28. Tarduno, J.A.; Duncan, R.A.; Scholl, D.W.; Cottrel, R.D.; Steinberger, B.; Thordarson, T.; Kerr, B.C.; Neal, C.R.; Frey, F.A.; Torii, M.; et al. Motion of the Hawaiian hotspot: A paleomagnetic test. In Proceedings ODP, Initial Reports; Shipboard Scientific Party: College Station, TX, USA, 2002; Volume 197, pp. 1-125. [CrossRef]

29. Van de Flierdt, T.; Frank, M.; Lee, D.-C.; Halliday, A.N.; Reynolds, B.C.; Hein, J.R. New constraints on the sources and behavior of neodymium and hafnium in seawater from Pacific Ocean ferromanganese crusts. Geochim. Cosmochim. Acta 2004, 68, 3827-3843. [CrossRef]

30. Schlanger, S.O.; Campbell, J.F.; Jackson, M.W. Post-Eocene subsidence of the Marshall Islands recorded by drowned atolls on Harrie and Sylvania guyots. In Seamounts, Islands and Atolls, Geophysical Monograph Series 43; Keating, B.H., Fryer, P., Batiza, R., Boehlert, G.W., Eds.; American Geophysical Union: Washington, DC, USA, 1987; Volume 43, pp. 165-174. [CrossRef]

31. Hein, J.R.; Schwab, W.C.; Davis, A.S. Cobalt and platinum-rich ferromanganese crusts and associated substrate rocks from the Marshall Islands. Mar. Geol. 1988, 78, 255-283. [CrossRef]

32. Mel'nikov, M.E.; Pletnev, S.P.; Anokhin, V.M.; Sedysheva, T.E.; Ivanov, V.V. Volcanic edifices on guyots of the Magellan Seamounts (Pacific Ocean). Russ. J. Pac. Geol. 2016, 10, 435-442. [CrossRef]

33. Werner, R.; Hoernle, K.; Hauff, F.; Portnyagin, M.; Yogodzinsky, G.; Ziegler, A. (Eds.) RV SONNE Fahrtbericht/Cruise Report SO249 BERING-Origin and Evolution of the Bering Sea: An Integrated Geochronological, Volcanological, Petrological and Geochemical Approach, Leg 1: Dutch Harbor (U.S.A.)-Petropavlovsk-Kamchatsky (Russia), 05.06.2016-15.07.2016, Leg 2: Petropavlovsk-Kamchatsky (Russia)-Tomakomai (Japan), 16.07.2016-14.08.2016. Geomar Report, N. Ser. 030; Geomar Helmholtz-Zentrum für Ozeanforschung: Kiel, Germany, 2016; p. 451. [CrossRef]

34. Svininnikov, A.I.; S'edin, V.T. Physical properties of rocks of the Cenozoic volcanic complexes from the Sea of Japan/ / Tihookeanskaya geologiya. Ocean Geol. 1984, 3, 7-15.

35. Prokudin, V.G.; S'edin, V.T.; Valitov, M.G.; Medvedev, S.N. The central basin of the Sea of Japan-History and Tectonics. Vestn. KRAUNTs Nauk. Zemle 2018, 4, 82-104. [CrossRef]

36. Mikhailik, P.E.; Mikhailik, E.V.; Zarubina, N.V.; Barinov, N.N.; S'edin, V.T.; Lelikov, E.P. Composition and distribution of REE in ferromanganese crusts of the Belyaevsky and Medvedev Seamounts in the Sea of Japan. Russ. J. Pac. Geol. 2014, 8, 315-329. [CrossRef]

37. Chursanov, Y.V.; Starovoytov, A.V. Atomic absorption determination of gold in electrothermal atomizer after separation by coprecipitation with tellurium. Vestn. Tver Tech. Univ. 2013, 15, 18-24.

38. Mikhailik, E.V.; Khanchuk, A.I.; Mikhailik, P.E.; Barinov, N.N.; Zarubina, N.V. The first find of visible gold in ferromanganese crusts of the Pacific Ocean. Dokl. Earth Sci. 2013, 449, 422-426. [CrossRef]

39. Melnikov, M.E.; Pletnev, S.P. Age and formation conditions of the Co-rich manganese crust on guyots of the Magellan seamounts. Lithol. Miner. Resour. 2013, 48, 1-13. [CrossRef]

40. Ivanov, V.V.; Khanchuk, A.I.; Mikhailik, P.E. Nature of Native Gold in Ferromanganese Crusts on the Seafloor of the Northwestern Pacific Ocean. Dokl. Earth Sci. 2021, 497, 223-226. [CrossRef]

41. Hein, J.R.; Whisman, S. Resource potential of hydrothermal manganese deposits from global ocean. In Proceedings of the 28th Goldschmidt Conference, Boston, MA, USA, 12-17 August 2018; p. 1305.

42. Volokhin, Y.G.; Mikhailik, P.E.; Mikhailik, E.V. Minerals in Manganese Deposits of Belyaevsky Volcano, the Sea of Japan. Russ. J. Pac. Geol. 2020, 14, 340-362. [CrossRef]

43. Koschinsky, A.; Stascheit, A.; Bau, M.; Halbach, P. Effect phosphatization on the geochemical and mineralogical composition of marine ferromanganese crusts. Geochim. Cosmochim. 1997, 61, 4079-4094. [CrossRef]

44. Bau, M.; Dulski, P. Comparative study of yttrium and rare-earth elements behaviours in fluorine-rich hydrothermal fluids. Contrib. Miner. Petrol. 1995, 119, 213-223. [CrossRef]

45. Halbach, P.; Manheim, F.T.; Otten, P. Co-rich ferromanganese deposits in the marginal seamount regions of the Central Pacific Basin-results of the Midpac'81. Erzmetall 1982, 35, 447-453.

46. Hein, J.R.; Conrad, T.A.; Frank, M.; Christl, M.; Sager, W.W. Copper-nickel-rich, amalgamated ferromanganese crust-nodule deposits from Shatsky Rise, NW Pacific. Geochem. Geophys. Geosyst. 2012, 13, Q10022. [CrossRef]

47. McLennan, S.M. Rare earth elements in sedimentary rocks: Influence of provenance and sedimentary processes. In Geochemistry and Mineralogy of the Rare Earth Elements. Review Mineralogy; Lipin, B.R., McKay, G.A., Eds.; De Gruyter: Berlin, Germany, 1989; Volume 21, pp. 169-200.

48. Bau, M.; Koschinsky, A.; Dulski, P.; Hein, J.R. Comparison of the partitioning behaviors of yttrium, rare earth elements, and titanium between hydrogenetic marine ferromanganese crusts and seawater. Geochim. Cosmochim. 1996, 60, 1709-1725. [CrossRef]

49. Bau, M.; Schmidt, K.; Koschinsky, A.; Hein, J.R.; Kuhn, T.; Usui, A. Discriminating between different genetic types of marine ferro-manganese crusts and nodules based on rare earth elements and yttrium. Chem. Geol. 2014, 381, 1-9. [CrossRef]

50. Hein, J.R.; Koschinsky, A. 13.11-Deep-Ocean Ferromanganese Crusts and Nodules. In Treatise on Geochemistry, 2nd ed.; Holland, H.D., Turekian, K.K., Eds.; Elsevier: Amsterdam, The Netherlands, 2014; pp. 273-291. [CrossRef] 
51. Usui, A.; Nishimura, A. Submersible observations of hydrothermal manganese deposits on the Kaikata Seamount, Izu-Ogasawara (Bonin). Arc. Mar. Geol. 1992, 106, 203-216. [CrossRef]

52. Kuhn, T.; Bau, M.; Blum, N.; Halbach, P. Origin of negative Ce anomalies in mixed hydrothermal-hydrogenetic Fe-Mn crusts from the Central Indian Ridge. Earth Planet. Sci. Lett. 1998, 163, 207-220. [CrossRef]

53. Mikhailik, P.E.; Mikhailik, E.V.; Zarubina, N.V.; Blokhin, M.G. Distribution of rare-earth elements and yttrium in hydrothermal sedimentary ferromanganese crusts of the Sea of Japan (from phase analysis results). Russ. Geol. Geophys. 2017, 58, 1530-1542. [CrossRef]

54. McMurtry, G.M.; VonderHaar, D.L.; Eisenhauer, A.; Mahoney, J.J.; Yeh, H.-W. Cenozoic accumulation history of a Pacific ferromanganese crust. Earth Planet. Sci. Lett. 1994, 125, 105-118. [CrossRef]

55. Halbach, P.; Segl, M.; Puteanus, D.; Mangini, A. Co fluxes and growth rates in ferromanganese deposits from central Pacific seamount areas. Nature 1983, 304, 719-722. [CrossRef]

56. Halbach, P.; Puteanus, D. The influence of the carbonate dissolution rate on the growth and composition of Co-rich ferromanganese crusts from Central Pacific seamount areas. Earth Planet. Sci. Lett. 1984, 68, 73-87. [CrossRef]

57. Puteanus, D.; Halbach, P. Correlation of Co concentration and growth rate-A method for age determination of ferromanganese crusts. Chem. Geol. 1988, 69, 73-85. [CrossRef]

58. Emelyanova, T.A.; Lelikov, E.P.; Pugachev, A.A. Pliocene-Holocene Alkali-Basaltoid Volcanism of the Tsushima Basin of the Sea of Japan: New Geochemical and Geodynamic Data. Oceanology 2020, 60, 236-247. [CrossRef]

59. Mirlin, E.G.; Lygina, T.A.; Asavin, A.M.; Chesalova, E.I. Volcano-tectonic activity of ocean lithosphere in the eastern sector of the Pacific Ocean. Okeanol. Issled. 2019, 47, 198-222. [CrossRef]

60. Halbach, P.; Nakamura, K.; Wahsher, M.; Lange, J.; Sakai, H.; Kaselitz, L.; Hansen, R.-D.; Yamano, M.; Post, J.; Prause, B.; et al. Probable modern analogue of Kuroko-type massive sulphide deposits in the Okinawa trough back-arc basin. Nature 1989, 338, 496-499. [CrossRef]

61. Hannington, M.; Herzig, P.; Scott, S.; Thompson, G.; Rona, P. Comparative mineralogy and geochemistryof gold-bearing sulfide deposits on the mid-oceanic ridges. Mar. Geol. 1991, 101, 217-248. [CrossRef]

62. Lizasa, K.; Fiske, R.S.; Ishizuka, O.; Yuasa, M.; Hashimoto, J.; Ishibashi, J.; Naka, J.; Horii, Y.; Fujiwara, Y.; Imai, A.; et al. A Kuroko-type polymetallic sulfide deposit in a submarine silicic caldera. Science 1999, 283, 975-977. [CrossRef]

63. Volokhin, Y.G.; Karabtsov, A.A.; Ustinov, A.Y. Manganese Mineralization in the Mesozoic Siliceous Deposits of the Central Sikhote-Alin and Nadanhada-Alin. Russ. J. Pac. Geol. 2019, 13, 29-50. [CrossRef]

64. Puddephatt, R.J. The Chemistry of Gold; Elsevier: Amsterdam, The Netherlands, 1978; p. 274. [CrossRef]

65. Reith, F.; Rogers, S.L.; McPhail, D.C.; Webb, D. Biomineralization of Gold: Biofilms on Bacterioform Gold. Science 2006, 313, 233-236. [CrossRef] [PubMed]

66. Shuster, J.; Reith, F. Reflecting on Gold Geomicrobiology Research: Thoughts and Considerations for Future Endeavors. Minerals 2018, 8, 401. [CrossRef]

67. Pavlova, L.M.; Shumilova, L.P.; Radomskaya, V.I.; Sorokin, A.P.; Ivanov, V.V. Biosorption of Chemical Elements from Multicomponent Solutions by Microfungal Biomass. Dokl. Earth Sci. 2019, 488, 1178-1181. [CrossRef]

68. Berezhnaya, E.D.; Dubinin, A.V. Determination of the platinum-group elements and gold in ferromanganese nodule reference material NOD-A-1. Geochem. Int. 2017, 55, 218-224. [CrossRef] 